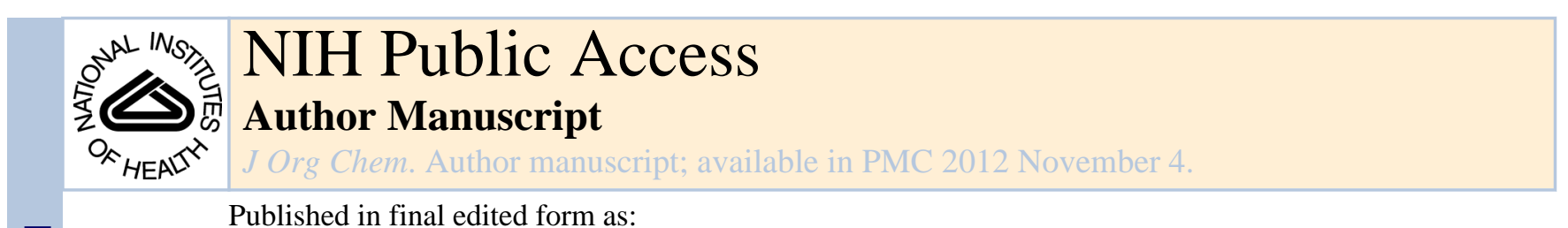

J Org Chem. 2011 November 4; 76(21): 8840-8851. doi:10.1021/jo201605v.

\title{
Synthesis of $2 \mathrm{H}$-Indazoles by the [3 + 2] Dipolar Cycloaddition of Sydnones with Arynes
}

\author{
Yuesi Fang ${ }^{\dagger}$, Chunrui $\mathbf{W u}^{*}, \neq$, Richard C. Larock ${ }^{*}, \dagger$, and Feng Shi ${ }^{*}, \neq$ \\ tDepartment of Chemistry, lowa State University, Ames, IA 50011, U.S.A \\ ¥Key Laboratory of Natural Medicine and Immuno-Engineering of Henan Province, Henan \\ University, Jinming Campus, Kaifeng, Henan 475004, China PR
}

\section{Abstract}

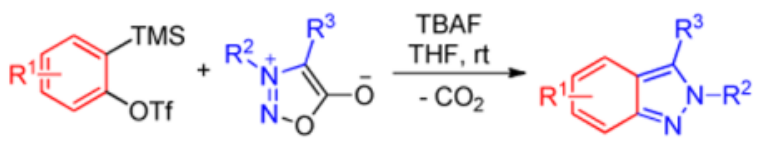

\begin{abstract}
A rapid and efficient synthesis of $2 \mathrm{H}$-indazoles has been developed using a [3+2] dipolar cycloaddition of sydnones and arynes. A series of $2 \mathrm{H}$-indazoles have been prepared in good to excellent yields using this protocol, and subsequent Pd-catalyzed coupling reactions can be applied to the halogenated products to generate a structurally diverse library of indazoles.
\end{abstract}

\section{Introduction}

The synthesis of heterocyclic compounds has attracted significant attention for decades. Among the various heterocycles, the indazole system has received significant attention due to its diverse bioactivity. ${ }^{1}$ Although a number of methods for the preparation of indazoles are known, most methods target $1 H$-indazoles. Those focused on the selective and efficient preparation of $2 \mathrm{H}$-indazoles, which also appear to have pharmaceutical promise, ${ }^{2}$ remain limited. Recently, significant efforts have been devoted to the development of synthetic routes towards $2 \mathrm{H}$-indazoles, ${ }^{3}$ as highlighted by the elegant chemistry developed by Halland (eq 1$)^{3 \mathrm{a}}$ and Song (eq 2)..$^{3 \mathrm{~b}}$ However, it should be noted that most of these methods still have significant limitations. Thus, new routes are still desirable.

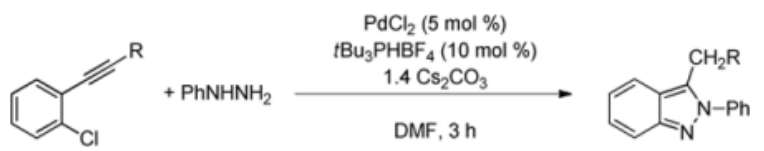

cwu@henu.edu.cn, larock@iastate.edu, fshi@henu.edu.cn.

Supporting Information Available: Detailed computational results, and full ${ }^{1} \mathrm{H}$ and ${ }^{13} \mathrm{C}$ NMR spectra. This material is available free of charge via the Internet at http://pubs.acs.org. 


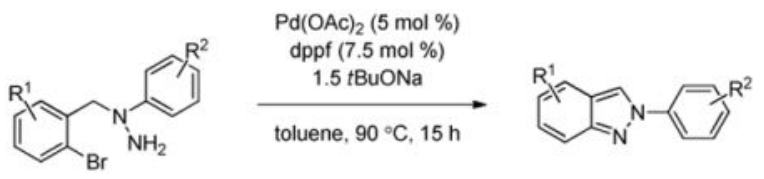

Our two groups have extensive ongoing research programs in aryne chemistry directed toward biologically important heterocycles, including approaches involving Pd-catalyzed annulation reactions, ${ }^{4}$ electrophilic and nucleophilic reactions, ${ }^{5}$ inter- or intramolecular annulation reactions, ${ }^{6}$ and insertion reactions. ${ }^{7}$ Aryne dipolar cycloadditions have provided synthetically useful methods for the synthesis of benzotriazoles, ${ }^{8}$ indazoles, ${ }^{9}$ and benzisoxazoles ${ }^{10}$ by reactions with azides, diazo compounds, and nitrile oxides, respectively.

For the synthesis of $2 \mathrm{H}$-indazoles, we have previously communicated a [3+2] cycloaddition approach involving arynes and readily accessible sydnones (eq 3). ${ }^{11}$ This chemistry, which offers very mild reaction conditions, high yields, and no contamination by $1 H$-indazoles, presumably involves an initial [3+2] cycloaddition to afford a bicyclic adduct, followed by spontaneous extrusion of a molecule of $\mathrm{CO}_{2}$ in a retro-[4+2] fashion. Herein, we wish to report the full details on this project, and demonstrate its potential application to the construction of a small library utilizing palladium-catalyzed crosscouplings of halogenated $2 \mathrm{H}$-indazoles prepared by our methodology.

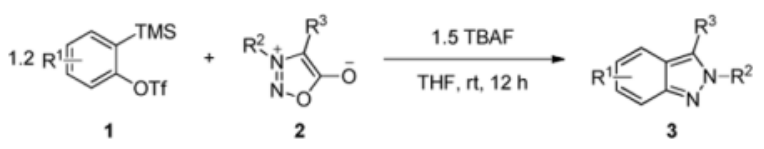

\section{Results and Discussion}

\section{Preparation of the sydnones}

Sydnones are readily prepared from the corresponding amino acids ${ }^{12}$ by a sequence which involves $N$-nitrosation/cyclodehydration. Three different protocols, namely Protocol $1 \mathrm{~A}$ [1.5 equiv of $\mathrm{NaNO}_{2}, 0^{\circ} \mathrm{C}, 1 \mathrm{~h}$, then acidify], Protocol $1 \mathrm{~B}$ [2.0 equiv of $\mathrm{NaNO}_{2}, \mathrm{HCl}$, then $0{ }^{\circ} \mathrm{C}$, $1 \mathrm{~h}]$, and Protocol 1C [1.5 equiv of $i$-amyl nitrite, DME, rt, $2 \mathrm{~d}]$ have been used in the nitrosation step, and two other protocols, namely $2 \mathrm{~A}\left[\mathrm{Ac}_{2} \mathrm{O}\right.$ as solvent, $110{ }^{\circ} \mathrm{C}, 2 \mathrm{~h}$ ] and $2 \mathrm{~B}$ [2 equiv of TFAA, $\mathrm{Et}_{2} \mathrm{O}, \mathrm{rt}, 2 \mathrm{~h}$ ] have been used for the cyclodehydration step. A variety of sydnones have been synthesized starting from readily available amino acids (Scheme 1, see the Experimental Section for details). However, preparation of some sydnones, especially those with an alkyl group at the $C$-4 position have not been successful.

Sydnones not readily derived from amino acids can be accessed by further functionalization of preformed monosubstituted sydnones. Thus, arylation and vinylation at the $C-4$ position of sydnones can be achieved from monosubstituted sydnones by Pd-catalyzed crosscoupling with aryl or vinylic halides using literature procedures (eq 4). ${ }^{13}$ Alkynylation at the $C-4$ position can be performed using the same protocol or by oxidative coupling with terminal alkynes (eq 5). ${ }^{14}$ Monosubstituted sydnones can also be iodinated ${ }^{15}$ or acylated ${ }^{16}$ at the $C$-4 position by reacting sydnones with $\mathrm{ICl}$ buffered with $\mathrm{NaOAc} / \mathrm{AcOH}$ (eq 6) or acetic anhydride combined with NBS (eq 7) respectively. 

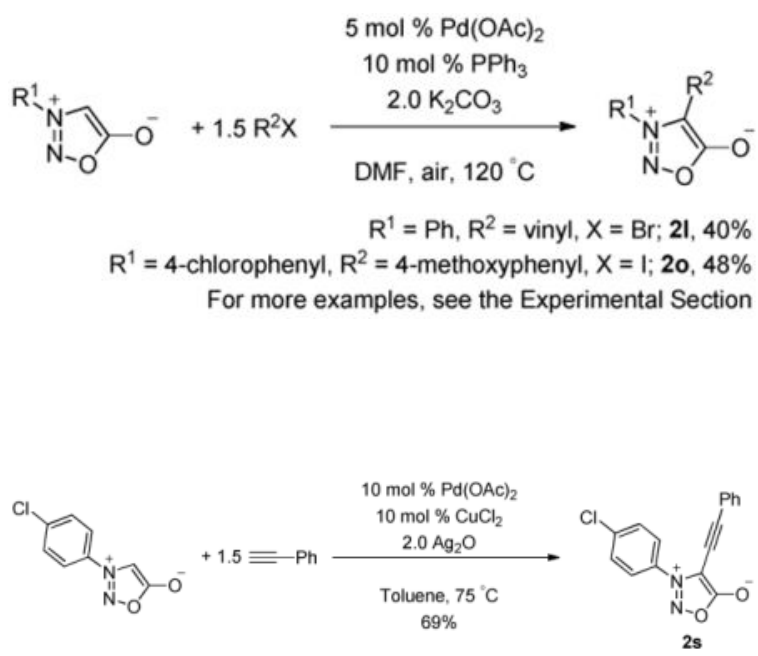

(5)<smiles></smiles>
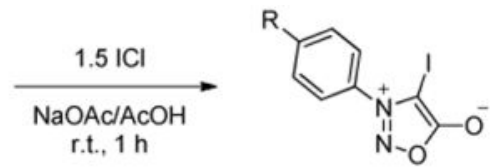

$\mathrm{R}=\mathrm{H} ; \mathbf{2 t}, 63 \%$

$\mathrm{R}=\mathrm{Br} ; 2 \mathrm{u}, 60 \%$

(6)

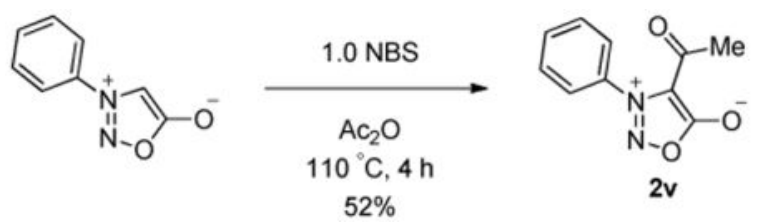

(7)

\section{Reaction optimization}

The reaction of $o$-(trimethylsilyl)phenyl triflate (1a) and $N$-phenylsydnone (2a) was investigated as the model reaction for optimization (Table 1). In the beginning, we found that using CsF in acetonitrile only afforded a 69\% yield of 3aa with incomplete conversion of 2a, even upon a prolonged reaction time (entry 1). Running the reaction in THF led to complete conversion with a much improved $90 \%$ yield (entry 2 ). We quickly found that better results and shorter reaction times could be realized by changing the fluoride source from $\mathrm{CsF}$ to TBAF (entries 3 and 4). With this change, THF and acetonitrile exhibited no apparent difference in yields. However, THF is slightly preferred, because it appeared to afford a pure product (white vs. yellow in acetonitrile). In addition, when using THF as the solvent, the loadings of both 1a and fluoride could be reduced while maintaining a near quantitative yield (entries 5 and 6). The reaction provides a clean, spot-to-spot transformation with perhaps only a trace of the starting material; no other spots were observed on TLC analysis. This sydnone-aryne cycloaddition appears to represent one of the 
best approaches to $2 \mathrm{H}$-indazoles in terms of efficiency and yield. The reaction conditions reported in Table 1, entries 5 and 6 , which employ the same stoichiometry and concentration, but use of either solid TBAF or a THF solution of TBAF afford similar results. Thus, the procedures reported in entries 5 and 6 have been chosen as our standard reaction conditions for our study of additional substrates.

\section{Scope and limitations}

The scope and limitations of our approach to $2 \mathrm{H}$-indazoles have been tested, first using a range of structurally diverse sydnones (Table 2). For monosubstituted sydnones with an aryl group, the reaction smoothly afforded excellent yields of the corresponding $2 \mathrm{H}$-indazoles (entries 1-6), with a variety of functional groups tolerated, including halogens (entries 2 and 3 ), and alkyl (entry 4), ether (entry 5), and acetal (entry 6) groups. However, the electron deficient $N$-(4-nitrophenyl)sydnone $\mathbf{2 g}$ (entry 7) was found to be unreactive. Even with the addition of a second batch of 1.2 equiv of $\mathbf{1 a}$ after the first 1.2 equiv of $\mathbf{1 a}$ was consumed, $2 \mathrm{~g}$ remained unreacted. $N$-Alkylsydnones (entries 8 and 9 ) also worked well under our reaction conditions, but in somewhat lower yields.

With substitution in the $C$-4 position of the sydnone, we have observed limited success with alkyl groups. Except for the proline-derived sydnone $\mathbf{2 j}$ (entry 10), which has the 3- and 4substitution tethered into a ring, other sydnones were found unstable under our reaction conditions and afforded a fairly complex reaction mixture in the end. For example, sydnone $2 \mathbf{k}$ derived from leucine (entry 11 ) afforded only a $23 \%$ yield with $\sim 10 \%$ recovery of the sydnone under our standard conditions, and 1.6 equiv of $\mathbf{1 a}$ and 2.4 equiv of TBAF had to be employed for the full conversion of $\mathbf{2 k}$. On the other hand, sydnones with $s p^{2}$ - or $s p$ carbon units in the $C-4$ position, including a vinyl group (entry 12), different aryl groups varying in their electronics (entries 13-16), different heterocyclic groups (entries 17 and 18), and an alkynyl group (entry 19), were all tolerated and the desired products were obtained in good to excellent yields, although in some cases (entries 18 and 19), incomplete conversion was observed. Successful substitution at the $C$-4 position of the sydnone has been extended to halogens, as illustrated in sydnones $2 \mathbf{t}$ and $\mathbf{2 u}$ (entries 20 and 21), where $88 \%$ and $90 \%$ yields have been obtained. However, substitution of other electron-withdrawing groups at the $C$-4 position has not been tolerated. For example, 4 -acetylsydnone $2 \mathbf{v}$ was found to be unreactive with benzyne under our standard conditions (entry 22), leading to complete recovery of the starting sydnone. The adverse effect of electron-withdrawing groups has also been observed in entry 13 , where a lower yield was obtained.

Next, a variety of different aryne precursors have been tested under our optimized reaction conditions (Table 3). As can be seen, excellent yields can be achieved regardless of the aryne structure. Symmetrical aryne precursors $\mathbf{1 b}$ and $\mathbf{1 c}$ have been converted to the corresponding $2 \mathrm{H}$-indazoles $\mathbf{3 b a}$ (entry 1 ) and $\mathbf{3 c a}$ (entry 2), respectively in almost quantitative yields. Unsymmetrical aryne precursor 1d, which is neither electronically nor sterically biased, afforded mixtures of two possible regioisomers in nearly equal amounts (entry 3). Unsymmetrical aryne precursor 1e, which is partially biased electronically, led to an inseparable mixture of two isomers in a $1: 0.8$ ratio (entry 4). Unsymmetrical aryne precursor 1f, which is slightly biased by sterics, led to an inseparable mixture of two isomers in a $1: 0.7$ ratio (entry 5). An unsymmetrical naphthalyne precursor $\mathbf{1 g}$ was also reactive and led to an inseparable mixture of two isomers in equal amounts (entry 6). However, 2,3pyridyne precursor $1 \mathbf{h}^{17}$ proved unsuccessful using our standard reaction conditions. We observed that all sydnone starting material was recovered when compound $\mathbf{1 h}$ was consumed (entry 7).

An interesting observation was made when we carried out the reaction using the unsymmetrical aryne precursor $\mathbf{1 i}$, which is both sterically and electronically biased. While 
we isolated two products, we were only able to assign one as the 4-MeO isomer (3ia) (33\% yield) through extensive NMR spectroscopic analysis and comparison with literature values. ${ }^{11,18}$ We were unable to identify the other product. While HRMS suggested the identity as the desired regioisomeric product, the presence of extra aromatic protons, as well as two aliphatic methyl groups in the ${ }^{1} \mathrm{H}$ NMR spectrum, clearly suggested otherwise. It was not until we reacted $\mathbf{1 i}$ with another sydnone $\mathbf{2 d}$ that we realized what had happened. In the latter reaction, we again obtained two products. One was the desired 4-MeO isomer (3id) in a $44 \%$ yield, and the other product was again unidentified. However, we were able to observe exactly the same extra aromatic protons and exactly the same extra methyl signals that were observed in the previously unidentified product, but here the integration no longer involved integers. That clearly suggested that these "unidentified" products were in fact mixtures of two compounds. The mixture obtained from 1i and 2a involved approximately a 1:1 ratio of two products. Therefore, the HRMS information was correct. The "unidentified" product from $1 \mathbf{i}$ and $\mathbf{2 a}$ actually contained the 7-MeO isomer 3ia'. The other component in the mixture was later attributed to $m$-anisidine based on ${ }^{1} \mathrm{H}$ NMR spectral analysis and comparison with literature values. The existence of $m$-anisidine was also confirmed by GCMS. Thus, by stirring this "unidentified" product with an excess of acetic anhydride and pyridine, followed by a regular work-up and silica gel chromatography, the pure 7-MeO isomer (3ia') could be obtained in a $40 \%$ yield. The ${ }^{1} \mathrm{H}$ NMR spectral data now matched the literature values. ${ }^{18}$ Similarly, compound 3id', the $7-\mathrm{MeO}$ isomer from the reaction of $\mathbf{1 i}$ and 2d, could be isolated pure in about a $42 \%$ yield.

The regioselectivity in this cycloaddition, especially with the aryne derived from $\mathbf{1 i}$, can be explained as shown in Scheme 2. For a sydnone, there are three resonance structures (A, B, and $\mathbf{C}$, Scheme 2), and cycloaddition with the aryne should arise from the latter two. Since the aryne derived from $1 \mathbf{i}$ is known to be attacked preferentially by nucleophiles at the meta position (with respect to the OMe group) for both electronic and steric reasons, ${ }^{19}$ resonance structure $\mathbf{B}$ should lead to formation of the 7-OMe regioisomer 3ia', while resonance structure $\mathbf{C}$ should lead to formation of the 4-OMe regioisomer $\mathbf{3 i a}$. While we typically draw the structure of sydnones as either $\mathbf{A}$ or $\mathbf{B}$, computational chemists long ago realized that despite the enolate nature and the observed nucleophilic reactivity of $C-4$, the $N-2$ position actually carries a significant negative charge ${ }^{20}$ and may serve as the nucleophile in the aryne reaction. Although the charge distribution of sydnones has been controversial, ${ }^{21}$

experimental results involving the cycloaddition of sydnones with unsymmetrical alkynes have clearly suggested that both $N-2$ and $C-4$ can react as the nucleophilic site. ${ }^{22}$ Moreover, the molecular orbital analysis of sydnones indicates that the LUMO of sydnones has very similar coefficients for $\mathrm{N}-2$ and $\mathrm{C}-4,{ }^{23}$ rendering the $\mathrm{N}-2$ and $\mathrm{C}-4$ positions of a sydnone similar in reactivity. All these literature results support the formation of both isomers 3ia and 3ia' through cycloaddition, and the side-product, $m$-anisidine, appears to arise from a separate path during the formation of isomer 3ia. Possibly, due to steric hindrance of the methoxy group, the $[3+2]$ cycloaddition to form $3 \mathbf{i a}$ is partially disrupted and therefore occurs stepwise, which stops at betaine $\mathbf{D} .{ }^{24}$ The addition of water may lead to the formation of $\mathbf{E}$, which is attacked by hydroxide to form a ring-opened intermediate $\mathbf{F}$. Intermediate $\mathbf{F}$ can further decompose to nitroso compound $\mathbf{G}$, which is then reduced to $m$-anisidine.

\section{Mechanistic investigation}

To gain further insight into this reaction, we conducted a brief Density Functional Theory and $a b$ initio calculation of the reaction path using Gaussian 09 . Geometry optimizations were performed with hybrid B3LYP functions in conjunction with the 6-31G(d) basis set. Higher-level relative energies were computed at the MP2/6-311+G(d,p) level based on the B3LYP/6-31G(d) optimized geometries. The schematic potential energy surface of the reaction with zero-point energy corrections is plotted in Figure 1. As can be seen, the initial 
$[3+2]$ cycloaddition is an exothermic step. A subsequent retro-[4+2] reaction is again exothermic. Since we were not able to find the transition states of these cycloaddition and cycloreversion processes, a relatively smooth potential energy surface may exist.

\section{Elaboration of $2 \mathrm{H}$-Indazoles}

As our approach to $2 \mathrm{H}$-indazoles tolerates halogen substituents, those halogen atoms offer an ideal site for further elaboration by subsequent Pd-catalyzed cross-couplings. Such a strategy can quickly afford a library of structurally diverse, highly functionalized $2 \mathrm{H}$ indazoles. In this regard, we have demonstrated the feasibility of such elaborations by converting 3at to the corresponding 3-aryl- and 3-(1-alkynyl)- $2 H$-indazoles using SuzukiMiyaura $^{25}$ and Sonogashira ${ }^{26}$ reactions, respectively (Scheme 3 ). ${ }^{27}$ By modifying the structure of the sydnones and arynes ${ }^{28}$ this approach can be easily exploited to provide more derivatives for potential biological activity screening. It should be noted that our direct new synthesis of alkynylsydnones ${ }^{14}$ is unable to prepare indazoles like 5at, and, therefore, the route described in Scheme 3 provides an effective route towards such compounds.

\section{Conclusions}

This work affords an efficient, new, synthetic route to $2 H$-indazoles by the [3+2] cycloaddition of arynes and sydnones. The reaction is applicable to a variety of sydnones and silylaryl triflates and affords the corresponding cycloadducts in moderate to excellent yields. Compared with literature protocols, our approach offers very mild reaction conditions, high yields, and no contamination by $1 H$-indazoles. The resulting halogensubstituted $2 \mathrm{H}$-indazoles are readily elaborated to more complex products using known organopalladium chemistry. Thus, the versatility of the cycloaddition and the tolerance of halogen make this methodology ideal for pharmaceutical chemistry.

\section{Experimental Section}

\section{General Information}

All reagents purchased from commercial sources were used as received. The solvents THF and $\mathrm{MeCN}$ were distilled over $\mathrm{Na} /$ benzophenone and $\mathrm{CaH}_{2}$, respectively. The aryne precursors were used as received; those not commercially available were prepared according to literature procedures. ${ }^{29,17}$ The sydnones were prepared as outlined below. The silica gel for column chromatography was supplied as 300-400 mesh or 230-400 mesh. ${ }^{30}$ Powdered CsF was used as received and stored in a desiccator. TBAF (either $1 \mathrm{M}$ in THF solution or anhydrous solid) was used as received. The solid TBAF was stored in a desiccator as well.

All melting points were measured and are uncorrected. The ${ }^{1} \mathrm{H}$ and ${ }^{13} \mathrm{C}$ NMR spectra were recorded and are referenced to the residual solvent signals $\left(7.26 \mathrm{ppm}\right.$ for ${ }^{1} \mathrm{H}$ in $\mathrm{CDCl}_{3}$ and $77.2 \mathrm{ppm}$ for ${ }^{13} \mathrm{C}$ in $\mathrm{CDCl}_{3}$ ).

All aryne cycloaddition reactions were carried out in oven-dried glassware and were magnetically stirred. A nitrogen atmosphere was not used, except that a balloon of nitrogen was attached to the reaction flask for the ventilation of $\mathrm{CO}_{2}$.

\section{Computational methods}

All electronic structure calculations involved in this work utilized the Gaussian 09 program package. ${ }^{31}$ The geometries and frequencies of all the stationary points (including reactants, intermediates, and products) were calculated by Becke's three-parameter nonlocal-exchange functional with the nonlocal correlation functional of Lee-Yang-Parr (B3LYP) using the 6-31G(d) basis set. To get more reliable reaction energies, single-point corrections were 
performed by restricted or unrestricted second-order Møller-Plesset perturbation theory (MP2) with the 6-311+G(d, p) basis set using the B3LYP optimized geometries.

\section{Preparation of the sydnones}

All the sydnones were prepared as follows. Due to long T1 relaxation times, the acquisition of ${ }^{13} \mathrm{C}$ NMR spectra for many sydnones could not be achieved, even after an overnight acquisition of 8000 scans on a $400 \mathrm{MHz}$ instrument.

\section{3-Phenylsydnone (2a)}

${ }^{12 \mathrm{a}}$ To a suspension of $5.00 \mathrm{~g}$ of $\mathrm{N}$-phenylglycine $(33 \mathrm{mmol})$ in $60 \mathrm{~mL}$ of water at $0{ }^{\circ} \mathrm{C}$ was added dropwise a solution of $3.50 \mathrm{~g}$ of $\mathrm{NaNO}_{2}(51 \mathrm{mmol}, 1.5$ equiv) in $20 \mathrm{~mL}$ of water. The mixture was stirred at $0{ }^{\circ} \mathrm{C}$ for an additional $20 \mathrm{~min}$ and the resultant clear red solution was filtered while cold. A scoop of activated charcoal (ca. 200-300 mg) was added and the mixture was stirred for a few minutes before being filtered again. The intermediate $\mathrm{N}$ nitroso- $N$-phenylglycine was precipitated from the filtrate by the addition of $10 \mathrm{~mL}$ of concentrated $\mathrm{HCl}$ and was then collected by filtration. It was washed with cold water and dried overnight under a high vacuum. The resulting solid was then dissolved in $25 \mathrm{~mL}$ of acetic anhydride and the mixture was heated to $100{ }^{\circ} \mathrm{C}$ for $1.5 \mathrm{~h}$. After being cooled to room temperature, the resulting mixture was poured into $300 \mathrm{~mL}$ of ice water. A yellow solid formed, which was triturated by stirring for a few minutes in this cold water. The solid was filtered, washed thoroughly with water until no smell of acetic acid remained, and dried under a high vacuum overnight to afford $3.37 \mathrm{~g}$ of product (63\% yield) as off-white crystals. This representative procedure for preparing sydnones from the corresponding amino acid is identified as Protocol 1: ${ }^{1} \mathrm{H}$ NMR (400 MHz, $\left.\mathrm{CDCl}_{3}\right) \delta$ 7.77-7.58 (m, $\left.5 \mathrm{H}\right), 6.75(\mathrm{~s}, 1 \mathrm{H})$.

\section{3-(4-Chlorophenyl)sydnone (2b)}

A mixture of $5.10 \mathrm{~g}$ of 4-chloroaniline $(40 \mathrm{mmol}), 5.14 \mathrm{~mL}$ of ethyl chloroacetate $(48 \mathrm{mmol}$, 1.2 equiv), and $6.53 \mathrm{~g}$ of $\mathrm{NaOAc} \cdot 3 \mathrm{H}_{2} \mathrm{O}(48 \mathrm{mmol}, 1.2$ equiv) in $10 \mathrm{~mL}$ of ethanol was refluxed in a $100{ }^{\circ} \mathrm{C}$ oil bath overnight. After being cooled to room temperature, the mixture was poured into ice water, and the precipitate was filtered and dried. The crude product, $N$ (4-chlorophenyl)glycine ethyl ester, after crystallization from ethanol (4.01 g, 47\% yield), was an off-white solid. It is strongly suggested that this intermediate be purified, either through recrystallization or column chromatography. The resulting ester $(3.00 \mathrm{~g}, 14 \mathrm{mmol})$ was stirred with $1.01 \mathrm{~g}$ of $\mathrm{LiOH}$ (3.0 equiv) in $30 \mathrm{~mL}$ of THF/water $(1: 1)$ at $0{ }^{\circ} \mathrm{C}$. After $2 \mathrm{~h}$ at $0{ }^{\circ} \mathrm{C}$, the reaction mixture was gradually warmed up to room temperature, where the $\mathrm{pH}$ was adjusted to 3-4 with concentrated $\mathrm{HCl}$. The precipitate was filtered and dried to afford $2.53 \mathrm{~g}$ of $\mathrm{N}$-(4-chlorophenyl)glycine (98\% yield) as an off-white solid (62\% overall yield). This representative procedure for preparing an amino acid is identified as Route $1 .{ }^{32}$ Sydnone $\mathbf{2 b}$ was then synthesized as an off-white solid (72\% overall yield) from the resulting amino acid following Protocol 1: ${ }^{1} \mathrm{H}$ NMR $\left(400 \mathrm{MHz}, \mathrm{CDCl}_{3}\right) \delta$ 7.74-7.67 (m, $2 \mathrm{H})$, 7.64-7.56 (m, 2H), $6.79(\mathrm{~s}, 1 \mathrm{H})$.

\section{3-(4-Bromophenyl)sydnone (2c)}

The corresponding amino acid was prepared from 4-bromoaniline following Route $\mathbf{1}$ in a $65 \%$ overall yield. Sydnone $2 \mathbf{c}$ was synthesized from this amino acid following Protocol 1 as an off-white solid (50\% overall yield): ${ }^{1} \mathrm{H}$ NMR $\left(400 \mathrm{MHz}, \mathrm{CDCl}_{3}\right) \delta 7.78(\mathrm{~d}, J=8.4 \mathrm{~Hz}$, $2 \mathrm{H}), 7.62(\mathrm{~d}, J=8.8 \mathrm{~Hz}, 2 \mathrm{H}), 6.73(\mathrm{~s}, 1 \mathrm{H})$.

\section{3-(4-Methylphenyl)sydnone (2d)}

The corresponding amino acid was prepared from 4-methylaniline following Route $\mathbf{1}$ in a $53 \%$ overall yield. Sydnone $\mathbf{2 d}$ was synthesized from this amino acid following Protocol 1 
as an off-white to cream solid (60\% overall yield): ${ }^{1} \mathrm{H}$ NMR (400 MHz, $\left.\mathrm{CDCl}_{3}\right) \delta 7.61$ (d, $J$ $=8.5 \mathrm{~Hz}, 2 \mathrm{H}), 7.42(\mathrm{~d}, J=8.2 \mathrm{~Hz}, 2 \mathrm{H}), 6.72(\mathrm{~s}, 1 \mathrm{H}), 2.49(\mathrm{~s}, 3 \mathrm{H})$.

\section{3-(4-Methoxyphenyl)sydnone (2e)}

The corresponding amino acid was prepared from 4-methoxylaniline following Route $\mathbf{1}$ in a $50 \%$ overall yield. Sydnone 2e was synthesized from this amino acid following Protocol 1 as an off-white solid (78\% overall yield): ${ }^{1} \mathrm{H}$ NMR $\left(400 \mathrm{MHz}, \mathrm{CDCl}_{3}\right) \delta 7.65(\mathrm{~d}, J=9.2 \mathrm{~Hz}$, $2 \mathrm{H}), 7.08(\mathrm{~d}, J=8.8 \mathrm{~Hz}, 2 \mathrm{H}), 6.64(\mathrm{~s}, 1 \mathrm{H}), 3.91(\mathrm{~s}, 3 \mathrm{H})$.

\section{3-(3,4-Methylenedioxyphenyl)sydnone (2f)}

The corresponding amino acid was prepared from 3,4-methylenedioxyaniline following Route $\mathbf{1}$ in a $60 \%$ overall yield. Sydnone $\mathbf{2 f}$ was synthesized from this amino acid following Protocol 1 as a brown solid (27\% overall yield): ${ }^{1} \mathrm{H}$ NMR $\left(400 \mathrm{MHz}, \mathrm{CDCl}_{3}\right) \delta$ 7.25-7.15 (m, $2 \mathrm{H}), 6.96(\mathrm{~d}, J=8.3 \mathrm{~Hz}, 1 \mathrm{H}), 6.64(\mathrm{~s}, 1 \mathrm{H}), 6.14(\mathrm{~s}, 2 \mathrm{H})$.

\section{3-(4-Nitrophenyl)sydnone (2g)}

To $0.75 \mathrm{~g}$ of glycine $(10 \mathrm{mmol})$ was added $10 \mathrm{~mL}$ of tetrabutylammonium hydroxide in methanol ( $1 \mathrm{M}, 10 \mathrm{mmol}, 1.0$ equiv.); the solvent was removed under vacuum, and the residue was dissolved in $20 \mathrm{~mL}$ of DMSO. $p$-Fluoronitrobenzene $(1.55 \mathrm{~g}, 11 \mathrm{mmol}, 1.1$ equiv) and $1.51 \mathrm{~g}$ of $\mathrm{K}_{2} \mathrm{CO}_{3}$ (11 mmol, 1.1 equiv) were added and the mixture was allowed to react under gentle warming $\left(45^{\circ} \mathrm{C}\right)$ with stirring until completion (monitored by TLC). The mixture was then poured into cold water, acidified with $\mathrm{HCl}$, and extracted with ethyl acetate. The combined organic layers were evaporated under vacuum and the residue was purified by column chromatography (5:1 petroleum ether/EtOAc) to afford $1.2 \mathrm{~g}(65 \%$ yield) of the desired amino acid as a yellow solid. ${ }^{33}$ Sydnone $\mathbf{2 g}$ was then synthesized from this amino acid following Protocol 1 as an off-white solid (36\% overall yield): ${ }^{1} \mathrm{H}$ NMR $\left(400 \mathrm{MHz}, \mathrm{CDCl}_{3}\right) \delta 8.52(\mathrm{~d}, J=8.8 \mathrm{~Hz}, 2 \mathrm{H}), 7,98(\mathrm{~d}, J=8.8 \mathrm{~Hz}, 2 \mathrm{H}), 6.84(\mathrm{~s}, 1 \mathrm{H})$.

\section{3-Methylsydnone (2h)}

To an ice-cold solution of $6.7 \mathrm{~mL}$ of conc. $\mathrm{HCl}$ and $3.56 \mathrm{~g}$ of sarcosine $(40 \mathrm{mmol})$ in $10 \mathrm{~mL}$ of water, was added a saturated solution of $5.52 \mathrm{~g}$ of $\mathrm{NaNO}_{2}(80 \mathrm{mmol})$ in water. The mixture was stirred at $0{ }^{\circ} \mathrm{C}$ for $1 \mathrm{~h}$ and then extracted with ethyl acetate three times. The combined organic layers were concentrated under a vacuum to obtain $N$-nitroso- $N$ methylglycine as a yellow oil. The resulting oil was dissolved in $4 \mathrm{~mL}$ of dry ether and charged dropwise with $\sim 500 \mu \mathrm{L}$ of trifluoroacetic anhydride $\left(3.6 \mathrm{mmol}, 1.8\right.$ equiv) at $0{ }^{\circ} \mathrm{C}$. The reaction was stirred at $0{ }^{\circ} \mathrm{C}$ for a few minutes and gradually warmed to room temperature and stirred for another $1 \mathrm{~h}$. The solvents were evaporated and the residue was dissolved in EtOAc. Solid $\mathrm{NaHCO}_{3}$ was added to neutralize the excess acid and was removed by filtration. The EtOAc was evaporated and the residue was purified by chromatography (2:1 petroleum ether/EtOAc) to yield $300 \mathrm{mg}$ of the desired sydnone ( $8 \%$ overall yield) as a yellow oil. This representative precedure for preparing sydnones from the corresponding amino acid is identified as Protocol 2: ${ }^{1} \mathrm{H} \mathrm{NMR}\left(400 \mathrm{MHz}, \mathrm{CDCl}_{3}\right) \delta 6.32$ (s, $1 \mathrm{H}), 4.07$ (s, $3 \mathrm{H})$.

\section{3-Benzylsydnone (2i)}

This sydnone was synthesized from $N$-benzylglycine as a white solid (39\% overall yield) following Protocol 2: ${ }^{1} \mathrm{H}$ NMR ( $400 \mathrm{MHz}, \mathrm{CDCl}_{3}$ ) $\delta 7.45$ (overlap, $3 \mathrm{H}$ ), 7.39 (overlap, 2 $\mathrm{H}), 6.21(\mathrm{~s}, 1 \mathrm{H}), 5.36(\mathrm{~s}, 2 \mathrm{H})$. 


\section{3,4-Cyclopenta[c]sydnone (2j)}

This sydnone was prepared according to a literature procedure ${ }^{34}$ as a brown oil ( $~ 11 \%$ overall yield).

\section{3-(4-Chlorophenyl)-4-(isobutyl)-sydnone (2k)}

To a round-bottom flask equipped with a stir bar, was added $1.32 \mathrm{~g}$ of L-leucine (10 mmol), followed by $190 \mathrm{mg}$ of $\mathrm{CuI}(1 \mathrm{mmol}, 10 \mathrm{~mol} \%), 3.04 \mathrm{~g}$ of anhydrous $\mathrm{K}_{2} \mathrm{CO}_{3}(22 \mathrm{mmol}, 2.2$ equiv.), $2.87 \mathrm{~g}$ of 4-bromochlorobenzene ( $15 \mathrm{mmol}, 1.5$ equiv.), and $9 \mathrm{~mL}$ of undistilled DMSO. The reaction system was flushed with nitrogen. The flask was sealed with a Teflon stopper and placed in a $70^{\circ} \mathrm{C}$ oil bath. The suspension was vigorously stirred. After $15 \mathrm{~h}$, the stirring was found to be difficult, and another $4 \mathrm{~mL}$ of DMSO was added. The reaction was stopped at $40 \mathrm{~h}$ when the color changed from a purple-brown to blue. The reaction was poured into ice water and concentrated $\mathrm{HCl}$ was added until the $\mathrm{pH}$ reached 3-4. The precipitate was filtered, washed thoroughly with cold water (slightly acidified by $\mathrm{HCl}$ to $\mathrm{pH}$ $\sim 4$ ) and dried under a high vacuum to yield $2.6 \mathrm{~g}$ of crude $\mathrm{N}$-(4-chlorophenyl)leucine as a slightly green solid (yield $>100 \%$ ). ${ }^{12 f, g}$ It should be noted that this method did not work for Met or Thr. This crude amino acid was used in the next step without further purification.

To a solution of $500 \mathrm{mg}$ ( $\sim 2 \mathrm{mmol}$ considering possible impurities) of crude $\mathrm{N}$-(4chlorophenyl)leucine in $3 \mathrm{~mL}$ of undistilled DME was added dropwise $\sim 400 \mu \mathrm{L}$ of isoamyl nitrite ( $3 \mathrm{mmol}, 1.5$ equiv) at room temperature. The mixture was allowed to stir for $2 \mathrm{~d}$ before the solvent was removed under reduced pressure. The solid was triturated with petroleum ether and filtered. The cake was washed with petroleum ether and air dried. The solid was dissolved in $4 \mathrm{~mL}$ of dry ether and was charged dropwise with $\sim 500 \mu \mathrm{L}$ of trifluoroacetic anhydride $\left(3.6 \mathrm{mmol}, 1.8\right.$ equiv) at $0{ }^{\circ} \mathrm{C}$. The reaction was stirred at $0{ }^{\circ} \mathrm{C}$ for a few minutes and gradually warmed to room temperature and stirred for another $1 \mathrm{~h}$. The solvents were evaporated and the residue was dissolved in EtOAc. The excess acid present was neutralized by the addition of solid $\mathrm{NaHCO}_{3}$, which was then removed by filtration. The EtOAc was evaporated and the residue was purified by chromatography (3:1 petroleum ether/EtOAc) to yield $130 \mathrm{mg}$ of the desired sydnone ( $26 \%$ overall yield) as a light brown oil: ${ }^{1} \mathrm{H}$ NMR (400 MHz, $\left.\mathrm{CDCl}_{3}\right) \delta 7.62(\mathrm{~d}, J=8.6 \mathrm{~Hz}, 2 \mathrm{H}), 7.46(\mathrm{~d}, J=8.7 \mathrm{~Hz}, 2 \mathrm{H}), 2.37$ $(\mathrm{d}, J=7.4 \mathrm{~Hz}, 2 \mathrm{H}), 1.88(\mathrm{dt}, J=13.6,6.8 \mathrm{~Hz}, 1 \mathrm{H}), 0.80(\mathrm{~d}, J=6.6 \mathrm{~Hz}, 6 \mathrm{H})$.

\section{3-(4-Chlorophenyl)-4-(4-methoxyphenyl)sydnone (20) $)^{13}$}

To a mixture of $197 \mathrm{mg}$ of $N$-(4-chlorophenyl)sydnone (1.0 mmol), $351 \mathrm{mg}$ of 4-iodoanisole (1.5 mmol, 1.5 equiv), $11 \mathrm{mg}$ of $\mathrm{Pd}(\mathrm{OAc})_{2}(0.05 \mathrm{mmol}, 5 \mathrm{~mol} \%), 26 \mathrm{mg}$ of $\mathrm{PPh}_{3}(0.1$ mmol, $10 \mathrm{~mol} \%$ ), and $276 \mathrm{mg}$ of anhydrous $\mathrm{K}_{2} \mathrm{CO}_{3}$ in a $10 \mathrm{~mL}$ round-bottom flask was added $2 \mathrm{~mL}$ of undistilled DMF. The flask was fitted with an air condenser and placed in a $120^{\circ} \mathrm{C}$ oil bath overnight, during which time the reaction mixture was stirred open to the air. The mixture was cooled to room temperature, poured into $30 \mathrm{~mL}$ of water, and extracted three times with EtOAc. The combined extracts were washed once with brine, dried over $\mathrm{MgSO}_{4}$, filtered, and evaporated. The residue was purified by column chromatography (petroleum ether/EtOAc) to afford $145 \mathrm{mg}$ of $\mathbf{2 o}$ as a yellow solid (48\% yield). This representative procedure for preparing functionalized sydnones is identified as Protocol 3: ${ }^{1} \mathrm{H}$ NMR (400 MHz, $\mathrm{CDCl}_{3}$ ) $\delta$ 7.57-7.51 (m, $\left.2 \mathrm{H}\right)$, 7.47-7.40 (m, $\left.2 \mathrm{H}\right)$, 7.24-7.17 (m, 2 $\mathrm{H}), 6.87-6.79(\mathrm{~m}, 2 \mathrm{H}), 3.79(\mathrm{~s}, 3 \mathrm{H})$.

\section{3-Phenyl-4-vinylsydnone (2l)}

This sydnone was prepared from sydnone $2 \mathbf{a}$ and vinyl bromide as a brown solid (40\% yield) following Protocol 3: ${ }^{1} \mathrm{H}$ NMR $\left(300 \mathrm{MHz}, \mathrm{CDCl}_{3}\right) \delta$ 7.79-7.60 $(\mathrm{m}, 3 \mathrm{H}), 7.59-7.50$ (m, 2 H), 6.40-6.16 (m, 2 H), 5.41 (d, $J=10.6 \mathrm{~Hz}, 1 \mathrm{H})$. 


\section{4-(4-Acetylphenyl)-3-phenylsydnone (2m)}

This sydnone was prepared from sydnone 2a and 4-bromoacetophenone as a yellow solid (30\% yield) following Protocol 3: ${ }^{1} \mathrm{H}$ NMR $\left(300 \mathrm{MHz}, \mathrm{CDCl}_{3}\right) \delta 7.83(\mathrm{~d}, J=7.7 \mathrm{~Hz}, 2 \mathrm{H})$, 7.76-7.56 (m, $3 \mathrm{H})$, 7.54-7.44 (m, $2 \mathrm{H}), 7.43-7.33$ (m, $2 \mathrm{H}), 2.54$ (s, $3 \mathrm{H})$.

\section{4-(4-Methoxyphenyl)-3-phenylsydnone (2n)}

This sydnone was prepared from sydnone 2a and 4-iodoanisole as a yellow solid (46\% yield) following Protocol 3: ${ }^{1} \mathrm{H}$ NMR $\left(400 \mathrm{MHz}, \mathrm{CDCl}_{3}\right) \delta 7.66(\mathrm{t}, J=7.2 \mathrm{~Hz}, 1 \mathrm{H}), 7.58(\mathrm{t}$, $J=7.2 \mathrm{~Hz}, 2 \mathrm{H}), 7.48(\mathrm{~d}, J=7.6 \mathrm{~Hz}, 2 \mathrm{H}), 7.22(\mathrm{~d}, J=8.8 \mathrm{~Hz}, 2 \mathrm{H}), 6.81(\mathrm{~d}, J=8.8 \mathrm{~Hz}, 2$ $\mathrm{H}), 3.78(\mathrm{~s}, 3 \mathrm{H})$.

\section{3,4-Bis(4-chlorophenyl)sydnone (2p)}

This sydnone was prepared from sydnone $\mathbf{2 b}$ and 4-bromochlorobenzene as a brown solid (44\% yield) following Protocol 3: ${ }^{1} \mathrm{H}$ NMR $\left(400 \mathrm{MHz}, \mathrm{CDCl}_{3}\right) \delta$ 7.60-7.55 (m, $\left.2 \mathrm{H}\right)$, 7.47-7.42 (m, 2 H), 7.31-7.27 (m, 2 H), 7.24 7.20 (m, 2 H).

\section{3-(4-Chlorophenyl)-4-(2-thiophenyl)sydnone (2q)}

This sydnone was prepared from sydnone $\mathbf{2 b}$ and 2-iodothiophene as a brown solid (50\% yield) following Protocol 3: ${ }^{1} \mathrm{H}$ NMR $\left(400 \mathrm{MHz}, \mathrm{CDCl}_{3}\right) \delta 7.65(\mathrm{~d}, J=8.4 \mathrm{~Hz}, 2 \mathrm{H}), 7.53$ $(\mathrm{d}, J=8.4 \mathrm{~Hz}, 2 \mathrm{H}), 7.35(\mathrm{~d}, J=3.7 \mathrm{~Hz}, 1 \mathrm{H}), 7.28(\mathrm{~d}, J=5.0 \mathrm{~Hz}, 1 \mathrm{H}), 7.02(\mathrm{t}, J=4.5 \mathrm{~Hz}$, $1 \mathrm{H})$.

\section{3-(4-Chlorophenyl)-4-(2-pyridyl)sydnone (2r)}

This sydnone was prepared from sydnone $\mathbf{2 b}$ and 2-bromopyridine as a brown solid (60\% yield) following Protocol 3: ${ }^{1} \mathrm{H}$ NMR $\left(400 \mathrm{MHz}, \mathrm{CDCl}_{3}\right) \delta 8.25(\mathrm{~d}, J=4.6 \mathrm{~Hz}, 1 \mathrm{H}), 8.11$ $(\mathrm{d}, J=8.0 \mathrm{~Hz}, 1 \mathrm{H}), 7.75(\mathrm{t}, J=7.8 \mathrm{~Hz}, 1 \mathrm{H}), 7.52(\mathrm{~d}, J=8.7 \mathrm{~Hz}, 2 \mathrm{H}), 7.45(\mathrm{~d}, J=8.7 \mathrm{~Hz}$, $2 \mathrm{H}), 7.13$ (dd, $J=7.4,4.9 \mathrm{~Hz}, 1 \mathrm{H})$.

\section{3-(4-Chlorophenyl)-4-(phenylethynyl)sydnone (2s) ${ }^{\mathbf{1 4}}$}

A solution of $79 \mathrm{mg}$ of sydnone $\mathbf{2 b}(0.4 \mathrm{mmol})$ in $2 \mathrm{~mL}$ of toluene was charged with $4.5 \mathrm{mg}$ of $\mathrm{Pd}(\mathrm{OAc})_{2}(5 \mathrm{~mol} \%), 6.8 \mathrm{mg}$ of $\mathrm{CuCl}_{2} \cdot 2 \mathrm{H}_{2} \mathrm{O}(10 \mathrm{~mol} \%)$, and $186 \mathrm{mg}$ of $\mathrm{Ag}_{2} \mathrm{O}(2.0$ equiv), and then heated to $75^{\circ} \mathrm{C}$ in an open flask. A solution of $88 \mu \mathrm{L}$ of phenylacetylene $(0.6 \mathrm{mmol})$ in $3 \mathrm{~mL}$ of toluene was added over $6 \mathrm{~h}$ using a syringe pump while the reaction was stirred open to the air. The reaction was allowed to stir for an additional $2 \mathrm{~h}$ after the addition, and then EtOAc and water were added. The layers were separated and the EtOAc was washed with brine, dried over $\mathrm{MgSO}_{4}$, filtered, and evaporated. The residue was purified by column chromatography (petroleum ether/EtOAc) to afford $82 \mathrm{mg}$ of $\mathbf{2 s}$ as a yellow solid (69\% yield): ${ }^{1} \mathrm{H}$ NMR $\left(400 \mathrm{MHz}, \mathrm{CDCl}_{3}\right) \delta$ 7.87-7.81 (m, $\left.2 \mathrm{H}\right)$, 7.67-7.61 (m, $2 \mathrm{H})$, 7.44-7.31 (m, $5 \mathrm{H})$.

\section{4-lodo-3-phenylsydnone (2t) ${ }^{15}$}

To a solution of $243 \mathrm{mg}$ of sydnone $\mathbf{2 a}(1.5 \mathrm{mmol})$ in $2.5 \mathrm{~mL}$ of acetic acid was added 185 $\mathrm{mg}$ of $\mathrm{NaOAc}$ ( $2.25 \mathrm{mmol}, 1.5$ equiv.), followed by a solution of $366 \mathrm{mg}$ of ICl ( $2.25 \mathrm{mmol}$, 1.5 equiv.) in $1.5 \mathrm{~mL}$ of acetic acid. The mixture was allowed to stir for $3 \mathrm{~h}$, then quenched with water and the solid was collected by filtration. The cake was washed with drops of cold ethanol and dried under vacuum to afford $272 \mathrm{mg}$ of product (63\%) as a brown solid. This representative procedure for preparing functionalized sydnones is identified as Protocol 4: ${ }^{1} \mathrm{H}$ NMR $\left(400 \mathrm{MHz}, \mathrm{CDCl}_{3}\right) \delta 7.73(\mathrm{t}, J=7.2 \mathrm{~Hz}, 1 \mathrm{H}), 7.67(\mathrm{t}, J=7.6 \mathrm{~Hz}, 2 \mathrm{H}), 7.60$ (d, $J=7.6 \mathrm{~Hz}, 2 \mathrm{H})$. 


\section{3-(4-Bromophenyl)-4-iodosydnone (2u)}

This sydnone was prepared from sydnone $2 \mathbf{c}$ as a brown solid (60\% yield) following Protocol 4: mp 160-162 ${ }^{\circ} \mathrm{C} ;{ }^{1} \mathrm{H}$ NMR $\left(400 \mathrm{MHz}, \mathrm{CDCl}_{3}\right) \delta 7.81(\mathrm{~d}, J=8.8 \mathrm{~Hz}, 2 \mathrm{H}), 7.50$ (d, $J=8.8 \mathrm{~Hz}, 2 \mathrm{H}$ ); LRMS (ESI) $367(\mathrm{M}+\mathrm{H})$; HRMS (ESI) calcd for $\mathrm{C}_{8} \mathrm{H}_{5} \mathrm{BrIN}_{2} \mathrm{O}_{2}(\mathrm{M}+\mathrm{H}$ ) 366.8574 , found 366.8574 .

\section{4-Acetyl-3-phenylsydnone (2v) ${ }^{16}$}

To a solution of $0.81 \mathrm{~g}$ of sydnone $\mathbf{2 a}(5 \mathrm{mmol})$ in $5 \mathrm{~mL}$ of acetic anhydride was added 0.89 $\mathrm{g}$ of NBS $(5 \mathrm{mmol})$. The mixture was allowed to stir for $4 \mathrm{~h}$, poured into $20 \mathrm{~mL}$ of ice water, and extracted by EtOAc. The combined organic layers were washed with saturated $\mathrm{NaHCO}_{3}$ solution, dried over $\mathrm{Na}_{2} \mathrm{SO}_{4}$, and evaporated under vacuum. The residue was purified by column chromatography (5:1 petroleum ether/EtOAc) to afford $529 \mathrm{mg}$ of product (52\% yield) as colorless crystals: ${ }^{1} \mathrm{H} \mathrm{NMR}\left(400 \mathrm{MHz}, \mathrm{CDCl}_{3}\right) \delta 7.83(\mathrm{~d}, J=7.6 \mathrm{~Hz}, 2 \mathrm{H}), 7.43$ (t, $J=8.0 \mathrm{~Hz}, 2 \mathrm{H}), 7.23(\mathrm{~d}, J=7.6 \mathrm{~Hz}, 1 \mathrm{H})$.

\section{General procedure for the synthesis of $\mathbf{2 H}$-indazoles}

To an oven-dried $10 \mathrm{~mL}$ round-bottom flask equipped with a stir bar were added $140 \mathrm{mg}$ of benzyne precursor ( $\sim .48 \mathrm{mmol}, \sim 1.2$ equiv) and $0.4 \mathrm{mmol}$ of sydnone. THF $(4 \mathrm{~mL})$ was added and the mixture was stirred until all solid dissolved. To this solution was added TBAF ( $\sim 160 \mathrm{mg}$ of solid or $\sim 630 \mu \mathrm{L}$ of $1 M$ THF solution, $\sim 1.6$ equiv) in one portion. The flask was sealed with a septum and a nitrogen balloon was attached. The reaction mixture was stirred at room temperature overnight. Upon completion, the reaction mixture was poured into saturated $\mathrm{NaHCO}_{3}$ and extracted three times with EtOAc. The combined extracts were washed once with brine, dried over $\mathrm{MgSO}_{4}$, filtered, and evaporated. The residue was purified by column chromatography (petroleum ether/EtOAc) to afford the $2 \mathrm{H}$-indazole.

\section{2-Phenyl-2H-indazole (3aa)}

Following the general procedure, this product was isolated as a white solid: $\mathrm{mp} 79-81{ }^{\circ} \mathrm{C}$ $\left(\mathrm{lit}^{35} 81-82{ }^{\circ} \mathrm{C}\right) ; R_{f}=0.45\left(6: 1\right.$ petroleum ether/EtOAc) $;{ }^{36}{ }^{1} \mathrm{H}$ NMR $\left(400 \mathrm{MHz}, \mathrm{CDCl}_{3}\right) \delta$ $8.41(\mathrm{~s}, 1 \mathrm{H}), 7.92-7.89(\mathrm{~m}, 2 \mathrm{H}), 7.81(\mathrm{dd}, J=8.8,0.9 \mathrm{~Hz}, 1 \mathrm{H}), 7.72(\mathrm{~d}, J=8.5 \mathrm{~Hz}, 1 \mathrm{H})$, 7.56-7.50 (m, $2 \mathrm{H}), 7.43-7.38$ (m, $1 \mathrm{H}), 7.34$ (ddd, $J=8.8,6.6,1.1 \mathrm{~Hz}, 1 \mathrm{H}), 7.12$ (ddd, $J=$ 8.4, 6.6, $0.8 \mathrm{~Hz}, 1 \mathrm{H}) ;{ }^{13} \mathrm{C} \mathrm{NMR}\left(100 \mathrm{MHz}, \mathrm{CDCl}_{3}\right) \delta 149.7,140.5,129.5,127.9,126.8$, 122.7, 122.4, 120.9, 120.40, 120.37, 117.9; LRMS (ESI): 217 (M+Na), 195 (M+H); HRMS (ESI): calcd for $\mathrm{C}_{13} \mathrm{H}_{11} \mathrm{~N}_{2}(\mathrm{M}+\mathrm{H})$ 195.0917, found 195.0916.

\section{2-(4-Chlorophenyl)-2H-indazole (3ab)}

White solid: $\mathrm{mp} 141-143{ }^{\circ} \mathrm{C} ; R_{f}=0.50\left(6: 1\right.$ petroleum ether/EtOAc) $;{ }^{36}{ }^{1} \mathrm{H}$ NMR $(400 \mathrm{MHz}$, $\left.\mathrm{CDCl}_{3}\right) \delta 8.39(\mathrm{~s}, 1 \mathrm{H}), 7.89-7.84(\mathrm{~m}, 2 \mathrm{H}), 7.77(\mathrm{~d}, J=8.8 \mathrm{~Hz}, 1 \mathrm{H}), 7.71(\mathrm{~d}, J=8.5 \mathrm{~Hz}, 1$ $\mathrm{H}), 7.53-7.48$ (m, $2 \mathrm{H}), 7.33$ (ddd, $J=8.6,6.6,0.8 \mathrm{~Hz}, 1 \mathrm{H}), 7.17-7.09(\mathrm{~m}, 1 \mathrm{H}) ;{ }^{13} \mathrm{C}$ NMR $\left(100 \mathrm{MHz}, \mathrm{CDCl}_{3}\right) \delta 149.8,138.9,133.5,129.7,127.1,122.8,122.7,122.0,120.35,122.30$, 117.8; LRMS (ESI) $251(\mathrm{M}+\mathrm{Na}), 229(\mathrm{M}+\mathrm{H})$; HRMS (ESI) calcd for $\mathrm{C}_{13} \mathrm{H}_{10} \mathrm{ClN}_{2}(\mathrm{M}+\mathrm{H})$ 229.0527, found 229.0525.

\section{2-(4-Bromophenyl)-2 $\mathrm{H}$-indazole (3ac)}

Yellow solid: mp 146-148 ${ }^{\circ} \mathrm{C} ; R_{f}=0.38\left(5: 1\right.$ petroleum ether/EtOAc); ${ }^{1} \mathrm{H}$ NMR $(400 \mathrm{MHz}$, $\left.\mathrm{CDCl}_{3}\right) \delta 8.36(\mathrm{~s}, 1 \mathrm{H}), 7.79-7.75(\mathrm{~m}, 3 \mathrm{H}), 7.68(\mathrm{~d}, J=8.4 \mathrm{~Hz}, 1 \mathrm{H}), 7.63(\mathrm{~d}, J=9.2 \mathrm{~Hz}, 2$ H), $7.32(\mathrm{dd}, J=7.6,6.8 \mathrm{~Hz}, 1 \mathrm{H}), 7.11(\mathrm{t}, J=7.6 \mathrm{~Hz}, 1 \mathrm{H}) ;{ }^{13} \mathrm{C} \mathrm{NMR}\left(100 \mathrm{MHz}, \mathrm{CDCl}_{3}\right) \delta$ 150.1, 139.7, 132.8, 127.3, 123.1, 122.9, 122.4, 121.6, 120.6, 120.4, 118.1; LRMS (ESI) 273 $(\mathrm{M}+\mathrm{H})$; HRMS (ESI) calcd for $\mathrm{C}_{13} \mathrm{H}_{10} \mathrm{BrN}_{2}(\mathrm{M}+\mathrm{H}) 273.0022$, found 273.0030 . 


\section{2-(4-Tolyl)-2H-indazole (3ad)}

White solid: mp 101-103 ${ }^{\circ} \mathrm{C} ; R_{f}=0.44$ (6:1 petroleum ether/EtOAc) $;{ }^{36}{ }^{1} \mathrm{H}$ NMR $(400 \mathrm{MHz}$, $\left.\mathrm{CDCl}_{3}\right) \delta 8.37(\mathrm{~d}, J=0.9 \mathrm{~Hz}, 1 \mathrm{H}), 7.83-7.76(\mathrm{~m}, 3 \mathrm{H}), 7.71(\mathrm{dt}, J=8.5,1.0 \mathrm{~Hz}, 1 \mathrm{H})$, 7.38-7.29 (m, $3 \mathrm{H}), 7.11$ (ddd, $J=8.4,6.6,0.8 \mathrm{~Hz}, 1 \mathrm{H}), 2.43$ (s, $3 \mathrm{H}) ;{ }^{13} \mathrm{C}$ NMR $(100 \mathrm{MHz}$, $\left.\mathrm{CDCl}_{3}\right) \delta 149.6,138.3,137.9,130.1,126.6,122.7,122.3,120.8,120.30,120.28,117.9$, 21.0; LRMS (ESI) $231(\mathrm{M}+\mathrm{Na}), 209(\mathrm{M}+\mathrm{H})$; HRMS (ESI) calcd for $\mathrm{C}_{14} \mathrm{H}_{13} \mathrm{~N}_{2}(\mathrm{M}+\mathrm{H})$ 209.1073, found 209.1072.

\section{2-(4-Methoxyphenyl)-2H-indazole (3ae)}

Yellow solid: mp $130-132{ }^{\circ} \mathrm{C} ; R_{f}=0.25\left(5: 1\right.$ petroleum ether/EtOAc); ${ }^{1} \mathrm{H}$ NMR $(400 \mathrm{MHz}$, $\left.\mathrm{CDCl}_{3}\right) \delta 8.30(\mathrm{~s}, 1 \mathrm{H}), 7.79(\mathrm{~d}, J=8.8 \mathrm{~Hz}, 3 \mathrm{H}), 7.69(\mathrm{~d}, J=8.4 \mathrm{~Hz}, 1 \mathrm{H}), 7.31(\mathrm{dd}, J=7.6$, $7.2 \mathrm{~Hz}, 1 \mathrm{H}), 7.10(\mathrm{t}, J=7.4 \mathrm{~Hz}, 1 \mathrm{H}), 7.01(\mathrm{~d}, J=8.8 \mathrm{~Hz}, 2 \mathrm{H}), 3.85(\mathrm{~s}, 3 \mathrm{H}) ;{ }^{13} \mathrm{C}$ NMR $\left(100 \mathrm{MHz}, \mathrm{CDCl}_{3}\right) \delta 159.4,149.7,134.3,126.7,122.8,122.6,122.4,120.5,120.4,117.9$, 114.8, 55.8; LRMS (ESI) 257 (M+Na), $225(\mathrm{M}+\mathrm{H})$; HRMS (ESI) calcd for $\mathrm{C}_{14} \mathrm{H}_{13} \mathrm{~N}_{2} \mathrm{O}$ (M $+\mathrm{H}) 225.1022$, found 225.1026 .

\section{2-(3,4-Methylenedioxyphenyl)-2 $\mathrm{H}$-indazole (3af)}

Pale white solid: $\mathrm{mp} 117-118{ }^{\circ} \mathrm{C} ; R_{f}=0.31$ (6:1 petroleum ether/EtOAc) $;{ }^{36} \mathrm{H}$ NMR $(400$ $\left.\mathrm{MHz}, \mathrm{CDCl}_{3}\right) \delta 8.29(\mathrm{~s}, 1 \mathrm{H}), 7.77(\mathrm{dd}, J=8.8,0.9 \mathrm{~Hz}, 1 \mathrm{H}), 7.69(\mathrm{~d}, J=8.5 \mathrm{~Hz}, 1 \mathrm{H}), 7.41$ $(\mathrm{d}, J=2.2 \mathrm{~Hz}, 1 \mathrm{H}), 7.35-7.29(\mathrm{~m}, 2 \mathrm{H}), 7.11$ (ddd, $J=8.4,6.6,0.8 \mathrm{~Hz}, 1 \mathrm{H}), 6.91(\mathrm{~d}, J=$ $8.4 \mathrm{~Hz}, 1 \mathrm{H}), 6.07(\mathrm{~s}, 2 \mathrm{H}) ;{ }^{13} \mathrm{C} \mathrm{NMR}\left(100 \mathrm{MHz}, \mathrm{CDCl}_{3}\right) \delta 149.1,148.4,147.3,135.2$, 126.7, 125.6, 122.3, 120.5, 120.2, 117.7, 114.4, 108.4, 103.1, 101.9; LRMS (ESI) 261 (M $+\mathrm{Na}), 239(\mathrm{M}+\mathrm{H})$; HRMS (ESI) calcd for $\mathrm{C}_{14} \mathrm{H}_{11} \mathrm{O}_{2} \mathrm{~N}_{2}(\mathrm{M}+\mathrm{H}) 239.0815$, found 239.0812 .

\section{2-Methyl-2H-indazole (3ah)}

Yellow oil: $R_{f}=0.21\left(2: 1\right.$ petroleum ether/EtOAc); ${ }^{1} \mathrm{H}$ NMR $\left(400 \mathrm{MHz}, \mathrm{CDCl}_{3}\right) \delta 7.88(\mathrm{~s}, 1$ H), $7.70(\mathrm{~d}, J=8.4 \mathrm{~Hz}, 1 \mathrm{H}), 7.64(\mathrm{~d}, J=8.4 \mathrm{~Hz}, 1 \mathrm{H}), 7.28(\mathrm{t}, J=7.2 \mathrm{~Hz}, 1 \mathrm{H}), 7.07(\mathrm{t}, J=$ $7.4 \mathrm{~Hz}, 1 \mathrm{H}), 4.21(\mathrm{~s}, 3 \mathrm{H}) ;{ }^{13} \mathrm{C} \mathrm{NMR}\left(100 \mathrm{MHz}, \mathrm{CDCl}_{3}\right) \delta 149.2,126.0,123.7,122.3$, 121.8, 120.1, 117.4, 40.5; LRMS (APCI) $133(\mathrm{M}+\mathrm{H})$; HRMS (APCI) calcd for $\mathrm{C}_{8} \mathrm{H}_{9} \mathrm{~N}_{2}$ (M $+\mathrm{H})$ 133.0760, found 133.0762.

\section{2-Benzyl-2H-indazole (3ai)}

Yellow oil: $R_{f}=0.31\left(5: 1\right.$ petroleum ether/EtOAc); ${ }^{1} \mathrm{H}$ NMR $\left(300 \mathrm{MHz}, \mathrm{CDCl}_{3}\right) \delta 7.86(\mathrm{~s}, 1$ H), $7.73(\mathrm{dd}, J=8.7,0.9 \mathrm{~Hz}, 1 \mathrm{H}), 7.61(\mathrm{~d}, J=8.4 \mathrm{~Hz}, 1 \mathrm{H}), 7.34-7.30(\mathrm{~m}, 3 \mathrm{H}), 7.27-7.23$ $(\mathrm{m}, 3 \mathrm{H}), 7.06(\mathrm{dd}, J=8.1,7.5 \mathrm{~Hz}, 1 \mathrm{H}), 5.57(\mathrm{~s}, 2 \mathrm{H}) ;{ }^{13} \mathrm{C} \mathrm{NMR}\left(100 \mathrm{MHz}, \mathrm{CDCl}_{3}\right) \delta$ 149.0, 135.9, 129.1, 128.5, 128.1, 126.2, 123.0, 122.2, 121.9, 120.3, 117.7, 57.6; LRMS (APCI) $209(\mathrm{M}+\mathrm{H})$; HRMS (APCI) calcd for $\mathrm{C}_{14} \mathrm{H}_{13} \mathrm{~N}_{2}(\mathrm{M}+\mathrm{H})$ 209.1073, found 209.1078.

\section{2,3-Dihydro-1 $H$-pyrrolo[1,2-b]indazole (3aj)}

Off-white solid: $\mathrm{mp} 99-100{ }^{\circ} \mathrm{C} ; R_{f}=0.31\left(1: 1 \mathrm{CH}_{2} \mathrm{Cl}_{2}\right.$ /EtOAc) $){ }^{36}{ }^{1} \mathrm{H} \mathrm{NMR}(400 \mathrm{MHz}$, $\left.\mathrm{CDCl}_{3}\right) \delta 7.67(\mathrm{~d}, J=8.7 \mathrm{~Hz}, 1 \mathrm{H}), 7.57(\mathrm{~d}, J=8.3 \mathrm{~Hz}, 1 \mathrm{H}), 7.26(\mathrm{t}, J=7.6 \mathrm{~Hz}, 1 \mathrm{H}), 7.03$ $(\mathrm{t}, J=7.5 \mathrm{~Hz}, 1 \mathrm{H}), 4.42(\mathrm{t}, J=7.3 \mathrm{~Hz}, 2 \mathrm{H}), 3.18(\mathrm{t}, J=7.2 \mathrm{~Hz}, 2 \mathrm{H}), 2.84-2.63(\mathrm{~m}, 2$ $\mathrm{H}) ;{ }^{13} \mathrm{C}$ NMR $\left(100 \mathrm{MHz}, \mathrm{CDCl}_{3}\right) \delta 153.5,138.8,125.5,120.3,119.8,117.6,116.1,48.9$, 25.7, 23.0; LRMS (ESI) $181(\mathrm{M}+\mathrm{Na}), 159(\mathrm{M}+\mathrm{H})$; HRMS (ESI) calcd for $\mathrm{C}_{10} \mathrm{H}_{11} \mathrm{~N}_{2}(\mathrm{M}+\mathrm{H})$ 159.0917, found 159.0915.

\section{2-(4-Chlorophenyl)-3-isobutyl-2H-indazole (3ak)}

Slightly orange solid: $\mathrm{mp} 77-79{ }^{\circ} \mathrm{C} ; R_{f}=0.47(6: 1$ petroleum ether/EtOAc) $) ;{ }^{1}{ }^{1} \mathrm{H}$ NMR $(400$ $\left.\mathrm{MHz}, \mathrm{CDCl}_{3}\right) \delta$ 7.72-7.68 (m, $\left.1 \mathrm{H}\right), 7.65(\mathrm{dt}, J=8.5,1.0 \mathrm{~Hz}, 1 \mathrm{H}), 7.55-7.44(\mathrm{~m}, 4 \mathrm{H}), 7.33$ (ddd, $J=8.8,6.6,1.1 \mathrm{~Hz}, 1 \mathrm{H}), 7.08(\mathrm{ddd}, J=8.5,6.6,0.8 \mathrm{~Hz}, 1 \mathrm{H}), 2.91(\mathrm{~d}, J=7.4 \mathrm{~Hz}, 2$ 
$\mathrm{H}), 2.04-1.89(\mathrm{~m}, 1 \mathrm{H}), 0.83(\mathrm{~d}, J=6.6 \mathrm{~Hz}, 6 \mathrm{H}) ;{ }^{13} \mathrm{C} \mathrm{NMR}\left(100 \mathrm{MHz}, \mathrm{CDCl}_{3}\right) \delta 148.6$, 138.7, 136.3, 134.8, 129.3, 127.6, 126.8, 121.5, 121.1, 120.4, 117.5, 34.1, 29.2, 22.5; LRMS (ESI) $307(\mathrm{M}+\mathrm{Na}), 285(\mathrm{M}+\mathrm{H})$; HRMS (ESI) calcd for $\mathrm{C}_{17} \mathrm{H}_{18} \mathrm{ClN}_{2}(\mathrm{M}+\mathrm{H}) 285.1153$, found 285.1151 .

\section{2-Phenyl-3-vinyl-2H-indazole (3al)}

Yellow gel: $R_{f}=0.18\left(5: 1\right.$ hexanes ether/EtOAc); ${ }^{1} \mathrm{H}$ NMR $\left(400 \mathrm{MHz}, \mathrm{CDCl}_{3}\right) \delta 7.92(\mathrm{~d}, J$ $=8.5 \mathrm{~Hz}, 1 \mathrm{H}), 7.79(\mathrm{~d}, J=8.7 \mathrm{~Hz}, 1 \mathrm{H}), 7.64-7.48(\mathrm{~m}, 5 \mathrm{H}), 7.43-7.34(\mathrm{~m}, 2 \mathrm{H}), 7.23-7.15$ $(\mathrm{m}, 1 \mathrm{H}), 6.81(\mathrm{dd}, J=17.8,11.6 \mathrm{~Hz}, 1 \mathrm{H}), 6.04(\mathrm{dd}, J=17.8,0.8 \mathrm{~Hz}, 1 \mathrm{H}), 5.53(\mathrm{dd}, J=$ $11.6,0.9 \mathrm{~Hz}, 1 \mathrm{H}) ;{ }^{13} \mathrm{C}$ NMR $\left(100 \mathrm{MHz}, \mathrm{CDCl}_{3}\right) \delta 148.8,139.6,133.2,129.1,128.8,126.7$, 126.2, 124.9, 122.7, 120.6, 120.3, 118.0, 117.7; LRMS (EI) 220 (M), 219 (M-H); HRMS (EI) calcd for $\mathrm{C}_{15} \mathrm{H}_{12} \mathrm{~N}_{2}$ (M) 220.1000, found 220.0990 .

\section{3-(4-Acetylphenyl)-2-phenyl-2 $\mathrm{H}$-indazole (3am)}

Yellow solid: $\mathrm{mp} 135-137{ }^{\circ} \mathrm{C}\left(1 \mathrm{it}{ }^{18} 136-138^{\circ} \mathrm{C}\right) ; R_{f}=0.36\left(2: 1\right.$ hexanes/EtOAc); ${ }^{1} \mathrm{H}$ NMR $\left(300 \mathrm{MHz}, \mathrm{CDCl}_{3}\right) \delta 7.97(\mathrm{~d}, J=8.1 \mathrm{~Hz}, 2 \mathrm{H}), 7.82(\mathrm{~d}, J=8.8 \mathrm{~Hz}, 1 \mathrm{H}), 7.72(\mathrm{~d}, J=8.5 \mathrm{~Hz}$, $1 \mathrm{H}), 7.47-7.36(\mathrm{~m}, 8 \mathrm{H}), 7.18(\mathrm{t}, J=7.6 \mathrm{~Hz}, 1 \mathrm{H}), 2.61(\mathrm{~s}, 3 \mathrm{H}) ;{ }^{13} \mathrm{C} \mathrm{NMR}(100 \mathrm{MHz}$, $\left.\mathrm{CDCl}_{3}\right) \delta 197.3,149.0,139.9,136.2,134.4,133.9,129.6,129.1,128.6,128.6,127.1,125.9$, 123.2, 121.8, 120.0, 117.9, 26.6; LRMS (EI) 312 (M); HRMS (EI) calcd for $\mathrm{C}_{21} \mathrm{H}_{16} \mathrm{~N}_{2} \mathrm{O}$ (M) 312.1263, found 312.1262.

\section{3-(4-Methoxyphenyl)-2-phenyl-2H-indazole (3an)}

Yellow solid: mp $103-105^{\circ} \mathrm{C} ; R_{f}=0.52\left(2: 1\right.$ hexanes/EtOAc); ${ }^{1} \mathrm{H}$ NMR $\left(400 \mathrm{MHz}, \mathrm{CDCl}_{3}\right)$ $\delta 7.79(\mathrm{~d}, J=8.4 \mathrm{~Hz}, 1 \mathrm{H}) ; 7.69(\mathrm{~d}, J=8.4 \mathrm{~Hz}, 1 \mathrm{H}), 7.39(\mathrm{~d}, J=2.4 \mathrm{~Hz}, 2 \mathrm{H}), 7.38-7.33(\mathrm{~m}$, $4 \mathrm{H}), 7.27(\mathrm{~d}, J=8.8 \mathrm{~Hz}, 2 \mathrm{H}), 7.12(\mathrm{t}, J=7.6 \mathrm{~Hz}, 1 \mathrm{H}), 6.91(\mathrm{~d}, J=8.8 \mathrm{~Hz}, 2 \mathrm{H}) ; 3.82(\mathrm{~s}, 3$ $\mathrm{H}) ;{ }^{13} \mathrm{C} \mathrm{NMR}\left(100 \mathrm{MHz}, \mathrm{CDCl}_{3}\right) \delta 159.7,149.0,140.4,135.5,131.1,129.1,128.3,127.1$, 126.1, 122.4, 122.2, 121.7, 120.8, 117.8, 114.4, 55.4; LRMS (EI) 300 (M); HRMS (EI) calcd for $\mathrm{C}_{20} \mathrm{H}_{16} \mathrm{~N}_{2} \mathrm{O}$ (M) 300.1263, found 300.1272 .

\section{2-(4-Chlorophenyl)-3-(4-methoxyphenyl)-2H-indazole (3ao)}

Slightly brown solid: $\mathrm{mp} 122-124{ }^{\circ} \mathrm{C} ; R_{f}=0.39$ (6:1 petroleum ether/EtOAc); ${ }^{36}{ }^{1} \mathrm{H}$ NMR $\left(400 \mathrm{MHz}, \mathrm{CDCl}_{3}\right) \delta 7.77(\mathrm{~d}, J=8.8 \mathrm{~Hz}, 1 \mathrm{H}), 7.68(\mathrm{~d}, J=8.5 \mathrm{~Hz}, 1 \mathrm{H}), 7.42-7.33(\mathrm{~m}, 5 \mathrm{H})$, 7.30-7.26 (m, $2 \mathrm{H}), 7.13$ (ddd, $J=8.4,6.6,0.7 \mathrm{~Hz}, 1 \mathrm{H}), 6.99-6.91(\mathrm{~m}, 2 \mathrm{H}), 3.86$ (s, $3 \mathrm{H}) ;{ }^{13} \mathrm{C} \mathrm{NMR}\left(100 \mathrm{MHz}, \mathrm{CDCl}_{3}\right) \delta 159.7,149.0,138.8,135.4,133.9,130.9,129.2,127.2$, 127.1, 122.4, 121.8, 121.7, 120.6, 117.6, 114.4, 55.3; LRMS (ESI) 357 (M+Na), 335 (M $+\mathrm{H}$ ); HRMS (ESI) calcd for $\mathrm{C}_{20} \mathrm{H}_{16} \mathrm{ClN}_{2} \mathrm{O}(\mathrm{M}+\mathrm{H}) 335.0946$, found 335.0942 .

\section{2,3-Bis(4-chlorophenyl)-2H-indazole (3ap)}

Pale white solid: $\mathrm{mp} 126-129{ }^{\circ} \mathrm{C} ; R_{f}=0.52(6: 1$ petroleum ether/EtOAc $) ;{ }^{36}{ }^{1} \mathrm{H} \mathrm{NMR}(400$ $\left.\mathrm{MHz}, \mathrm{CDCl}_{3}\right) \delta 7.79(\mathrm{~d}, J=8.8 \mathrm{~Hz}, 1 \mathrm{H}), 7.66(\mathrm{~d}, J=8.5 \mathrm{~Hz}, 1 \mathrm{H}), 7.43-7.35(\mathrm{~m}, 7 \mathrm{H})$, 7.32-7.27 (m, $2 \mathrm{H}), 7.17(\mathrm{ddd}, J=8.5,6.6,0.7 \mathrm{~Hz}, 1 \mathrm{H}) ;{ }^{13} \mathrm{C} \mathrm{NMR}\left(100 \mathrm{MHz}, \mathrm{CDCl}_{3}\right) \delta$ $149.1,138.4,134.7,134.3,134.1,130.8,129.35,129.29,128.0,127.4,127.1,123.1,121.8$, 120.1, 117.8; LRMS (ESI) $361(\mathrm{M}+\mathrm{Na}), 339(\mathrm{M}+\mathrm{H})$; HRMS (ESI) calcd for $\mathrm{C}_{19} \mathrm{H}_{13} \mathrm{Cl}_{2} \mathrm{~N}_{2}$ $(\mathrm{M}+\mathrm{H})$ 339.0450, found 339.0448.

\section{2-(4-Chlorophenyl)-3-(2-thiophenyl)-2H-indazole (3aq)}

Yellow solid: $\mathrm{mp} 99-101{ }^{\circ} \mathrm{C} ; R_{f}=0.49$ (6:1 petroleum ether/EtOAc).$^{36}$ The product spot overlapped with a highly fluorescent spot that immediately follows the product spot. Performing column chromatography with 8:1:0.4 petroleum ether $/ \mathrm{CH}_{2} \mathrm{Cl}_{2} / \mathrm{EtOAc}$ offers some help in separation and purification of the desired product: ${ }^{1} \mathrm{H}$ NMR $(400 \mathrm{MHz}$, $\left.\mathrm{CDCl}_{3}\right) \delta 7.82(\mathrm{~d}, J=8.5 \mathrm{~Hz}, 1 \mathrm{H}), 7.77(\mathrm{~d}, J=8.8 \mathrm{~Hz}, 1 \mathrm{H}), 7.49-7.35(\mathrm{~m}, 6 \mathrm{H}), 7.19(\mathrm{ddd}$, 
$J=8.4,6.6,0.8 \mathrm{~Hz}, 1 \mathrm{H}), 7.10(\mathrm{dd}, J=5.1,3.6 \mathrm{~Hz}, 1 \mathrm{H}), 7.03(\mathrm{dd}, J=3.6,1.1 \mathrm{~Hz}, 1 \mathrm{H}) ;{ }^{13} \mathrm{C}$ NMR $\left(100 \mathrm{MHz}, \mathrm{CDCl}_{3}\right) \delta 148.9,138.4,134.7,129.9,129.6,129.3,128.4,127.69,127.65$, 127.5, 127.3, 123.0, 121.9, 120.5, 117.7; LRMS (ESI) $333(\mathrm{M}+\mathrm{Na}), 311(\mathrm{M}+\mathrm{H})$; HRMS (ESI) calcd for $\mathrm{C}_{17} \mathrm{H}_{12} \mathrm{ClSN}_{2}(\mathrm{M}+\mathrm{H}) 311.0404$, found 311.0404. The contaminant (the fluorescent spot) shows a series of non-overlapped signals as follows: $7.87(\mathrm{~d}, J=8.5 \mathrm{~Hz}$ ), 7.50 (apparent t, $J=9.0 \mathrm{~Hz}), 7.13(\mathrm{~d}, J=3.8 \mathrm{~Hz}), 6.88(\mathrm{~d}, J=3.8 \mathrm{~Hz})$.

\section{2-(4-Chlorophenyl)-3-(2-pyridyl)-2H-indazole (3ar)}

Slightly brown solid: $\mathrm{mp} 137-139{ }^{\circ} \mathrm{C} ; R_{f}=0.25\left(6: 1\right.$ petroleum ether/EtOAc) $;{ }^{36}{ }^{1} \mathrm{H}$ NMR $\left(400 \mathrm{MHz}, \mathrm{CDCl}_{3}\right) \delta 8.71-8.67(\mathrm{~m}, 1 \mathrm{H}), 7.93(\mathrm{~d}, J=8.5 \mathrm{~Hz}, 1 \mathrm{H}), 7.81(\mathrm{~d}, J=8.8 \mathrm{~Hz}, 1 \mathrm{H})$, $7.71(\mathrm{td}, J=7.8,1.8 \mathrm{~Hz}, 1 \mathrm{H}), 7.44-7.36(\mathrm{~m}, 5 \mathrm{H}), 7.32(\mathrm{~d}, J=7.9 \mathrm{~Hz}, 1 \mathrm{H}), 7.29-7.24(\mathrm{~m}, 1$ H), 7.21 (ddd, $J=8.5,6.6,0.7 \mathrm{~Hz}, 1 \mathrm{H}) ;{ }^{13} \mathrm{C}$ NMR $\left(100 \mathrm{MHz}, \mathrm{CDCl}_{3}\right) \delta 150.2,149.2$, 149.1, 139.1, 136.5, 134.3, 134.1, 129.2, 127.3, 127.1, 124.6, 123.6, 122.6, 122.3, 120.7, 117.8; LRMS (ESI) $328(\mathrm{M}+\mathrm{Na}), 306(\mathrm{M}+\mathrm{H})$; HRMS (ESI) calcd for $\mathrm{C}_{18} \mathrm{H}_{13} \mathrm{ClN}_{3}(\mathrm{M}+\mathrm{H})$ 306.0793, found 306.0790.

\section{2-(4-Chlorophenyl)-3-phenylethynyl-2H-indazole (3as)}

Yellow solid: $\mathrm{mp} 141-144{ }^{\circ} \mathrm{C} ; R_{f}=0.50$ (6:1 petroleum ether/EtOAc).$^{36}$ The product spot overlapped with some spots that have a long wavelength UV absorption. Performing column chromatography with 8:1:0.4 petroleum ether/ $\mathrm{CH}_{2} \mathrm{Cl}_{2} / \mathrm{EtOAc}$ offers some help in separation and purification of the desired product. The impurities do not show more than minimum contamination by ${ }^{1} \mathrm{H}$ NMR spectroscopy: ${ }^{1} \mathrm{H}$ NMR $\left(400 \mathrm{MHz}, \mathrm{CDCl}_{3}\right) \delta$ 8.01-7.95 (m, $\left.2 \mathrm{H}\right)$, 7.87-7.78 (m, $2 \mathrm{H}), 7.58-7.49$ (m, $4 \mathrm{H}), 7.43-7.36$ (m, $4 \mathrm{H}), 7.25-7.21(\mathrm{~m}, 1 \mathrm{H}) ;{ }^{13} \mathrm{C}$ NMR $\left(100 \mathrm{MHz}, \mathrm{CDCl}_{3}\right) \delta 148.7,138.6,134.3,131.3,129.19,129.14,128.6,127.6,125.6,125.5$, 123.5, 121.9, 120.2, 118.2, 100.7, 77.7 (one overlapped signal); LRMS (ESI) 329 (M+H); HRMS (ESI) calcd for $\mathrm{C}_{21} \mathrm{H}_{14} \mathrm{ClN}_{2}(\mathrm{M}+\mathrm{H}) 329.0840$, found 329.0837 .

\section{3-lodo-2-phenyl-2H-indazole (3at)}

Off-white solid: $\mathrm{mp} 104-105{ }^{\circ} \mathrm{C} ; R_{f}=0.42\left(5: 1\right.$ petroleum ether/EtOAc); ${ }^{1} \mathrm{H}$ NMR (400 $\left.\mathrm{MHz}, \mathrm{CDCl}_{3}\right) \delta 7.74(\mathrm{~d}, J=8.8 \mathrm{~Hz}, 1 \mathrm{H}), 7.62(\mathrm{~d}, J=7.2 \mathrm{~Hz}, 2 \mathrm{H}), 7.50(\mathrm{~m}, 4 \mathrm{H}), 7.36(\mathrm{dd}$, $J=7.6,6.8 \mathrm{~Hz}, 1 \mathrm{H}), 7.16(\mathrm{t}, J=7.6 \mathrm{~Hz}, 1 \mathrm{H}) ;{ }^{13} \mathrm{C} \mathrm{NMR}\left(100 \mathrm{MHz}, \mathrm{CDCl}_{3}\right) \delta 150.1,140.6$, 129.4, 129.1, 128.4, 127.7, 126.8, 123.3, 121.2, 118.4, 76.2; LRMS (ESI) 321 (M+H); HRMS (ESI) calcd for $\mathrm{C}_{13} \mathrm{H}_{10} \mathrm{IN}_{2}(\mathrm{M}+\mathrm{H}) 320.9883$, found 320.9884 .

\section{2-(4-Bromophenyl)-3-iodo-2H-indazole (3au)}

Yellow solid: mp $159-161{ }^{\circ} \mathrm{C} ; R_{f}=0.38\left(5: 1\right.$ petroleum ether/EtOAc); ${ }^{1} \mathrm{H}$ NMR $(400 \mathrm{MHz}$, $\left.\mathrm{CDCl}_{3}\right) \delta 7.73(\mathrm{~d}, J=8.8 \mathrm{~Hz}, 1 \mathrm{H}), 7.68(\mathrm{~d}, J=8.4 \mathrm{~Hz}, 2 \mathrm{H}), 7.54(\mathrm{~d}, J=8.8 \mathrm{~Hz}, 2 \mathrm{H}), 7.47$ $(\mathrm{d}, J=8.4 \mathrm{~Hz}, 1 \mathrm{H}), 7.38(\mathrm{t}, J=7.4 \mathrm{~Hz}, 1 \mathrm{H}), 7.18(\mathrm{t}, J=7.4 \mathrm{~Hz}, 1 \mathrm{H}) ;{ }^{13} \mathrm{C}$ NMR $(100 \mathrm{MHz}$, $\left.\mathrm{CDCl}_{3}\right) \delta 150.4,139.6,132.5,132.4,128.7,128.4,128.0,123.6,121.3,118.5,76.0 ;$ LRMS (ESI) $399(\mathrm{M}+\mathrm{H})$; HRMS (ESI) calcd for $\mathrm{C}_{13} \mathrm{H}_{9} \mathrm{BrIN}_{2}(\mathrm{M}+\mathrm{H}) 398.8988$, found 398.8988 .

\section{5,6-Dimethyl-2-phenyl-2H-indazole (3ba)}

White solid: $\mathrm{mp} 133-135{ }^{\circ} \mathrm{C} ; R_{f}=0.24\left(5: 1\right.$ hexanes/EtOAc); ${ }^{1} \mathrm{H}$ NMR $\left(400 \mathrm{MHz}, \mathrm{CDCl}_{3}\right) \delta$ $8.21(\mathrm{~s}, 1 \mathrm{H}), 7.87$ (d, $J=7.8 \mathrm{~Hz}, 2 \mathrm{H}), 7.56(\mathrm{~s}, 1 \mathrm{H}), 7.49(\mathrm{t}, J=7.8 \mathrm{~Hz}, 2 \mathrm{H}), 7.40$ (s, $2 \mathrm{H})$, $7.36(\mathrm{t}, J=7.4 \mathrm{~Hz}, 1 \mathrm{H}), 2.39(\mathrm{~s}, 3 \mathrm{H}), 2.34(\mathrm{~s}, 3 \mathrm{H}) ;{ }^{13} \mathrm{C} \mathrm{NMR}\left(100 \mathrm{MHz}, \mathrm{CDCl}_{3}\right) \delta 149.6$, $140.5,137.2,132.3,129.4,127.3,121.8,120.5,119.0,118.6,116.5,21.1,20.5$; LRMS (EI) 222 (M), 207 (M-Me); HRMS (EI) calcd for $\mathrm{C}_{15} \mathrm{H}_{14} \mathrm{~N}_{2}$ (M) 222.1157, found 222.1155.

\section{5,6-Dimethoxy-2-phenyl-2H-indazole (3ca)}

White solid: $\mathrm{mp} 147-148{ }^{\circ} \mathrm{C}\left(\mathrm{lit}^{37} 149-150{ }^{\circ} \mathrm{C}\right) ; R_{f}=0.26\left(2: 1\right.$ hexanes/EtOAc); ${ }^{1} \mathrm{H}$ NMR $\left(400 \mathrm{MHz}, \mathrm{CDCl}_{3}\right) \delta 8.21(\mathrm{~s}, 1 \mathrm{H}), 7.84(\mathrm{~d}, J=7.7 \mathrm{~Hz}, 2 \mathrm{H}), 7.49(\mathrm{t}, J=7.9 \mathrm{~Hz}, 2 \mathrm{H}), 7.34$ 
$(\mathrm{t}, J=7.4 \mathrm{~Hz}, 1 \mathrm{H}), 7.06(\mathrm{~s}, 1 \mathrm{H}), 6.89(\mathrm{~s}, 1 \mathrm{H}), 3.97(\mathrm{~s}, 3 \mathrm{H}), 3.93(\mathrm{~s}, 3 \mathrm{H}) ;{ }^{13} \mathrm{C} \mathrm{NMR}(75$ $\left.\mathrm{MHz}, \mathrm{CDCl}_{3}\right) \delta 152.0,148.4,146.6,140.5,129.5,127.0,120.0,119.1,117.4,96.9,95.8$, 55.9; LRMS (EI) 254 (M); HRMS (EI) calcd for $\mathrm{C}_{15} \mathrm{H}_{14} \mathrm{~N}_{2} \mathrm{O}_{2}$ (M) 254.1055, found 254.1059.

\section{5-Methyl-2-phenyl-2H-indazole and 6-methyl-2-phenyl-2H-indazole (3da + 3da')}

Slightly yellow solid: $R_{f}=0.26\left(5: 1\right.$ hexanes/EtOAc); ${ }^{1} \mathrm{H}$ NMR $\left(400 \mathrm{MHz}, \mathrm{CDCl}_{3}\right.$, mixture of isomers, two sets of signals) $\delta 8.32(\mathrm{~s}, 1 \mathrm{H}), 8.27(\mathrm{~s}, 1 \mathrm{H}), 7.89(\mathrm{~s}, 2 \mathrm{H}), 7.87(\mathrm{~s}, 2 \mathrm{H})$, $7.71(\mathrm{~d}, J=8.9 \mathrm{~Hz}, 1 \mathrm{H}), 7.59(\mathrm{~d}, J=8.6 \mathrm{~Hz}, 1 \mathrm{H}), 7.53-7.47(\mathrm{~m}, 4 \mathrm{H}), 7.55(\mathrm{~s}, 1 \mathrm{H}), 7.43(\mathrm{~s}$, $1 \mathrm{H}), 7.41-7.34(\mathrm{~m}, 2 \mathrm{H}), 7.17(\mathrm{~d}, J=8.6 \mathrm{~Hz}, 1 \mathrm{H}), 6.96(\mathrm{~d}, J=8.5 \mathrm{~Hz}, 1 \mathrm{H}), 2.48(\mathrm{~s}, 3 \mathrm{H})$, $2.43(\mathrm{~s}, 3 \mathrm{H}) ;{ }^{13} \mathrm{C}$ NMR $\left(100 \mathrm{MHz}, \mathrm{CDCl}_{3}\right.$, mixture of isomers) $\delta 150.3,148.7,140.5$, 136.7, 131.7, 129.8, 129.4, 127.6, 125.4, 123.0, 121.1, 120.73, 120.70, 120.1, 119.8, 119.4, 118.3, 117.5, 116.1, 22.3, 21.8 (some overlap); LRMS (EI) 208 (M); HRMS (EI) calcd for $\mathrm{C}_{14} \mathrm{H}_{12} \mathrm{~N}_{2}$ (M) 208.1000, found 208.1003.

\section{5-Methoxy-2-phenyl-2H-indazole and 6-Methoxy-2-phenyl-2H-indazole (3ea + 3ea')}

Yellow solid: $R_{f}=0.25$ (5:1 hexanes/EtOAc); ${ }^{1} \mathrm{H}$ NMR (400 MHz, $\mathrm{CDCl}_{3}$, mixture of isomers, two sets of signals) $\delta 8.27(\mathrm{~s}, 1 \mathrm{H}), 8.22(\mathrm{~s}, 0.8 \mathrm{H}), 7.84(\mathrm{~d}, J=8.4 \mathrm{~Hz}, 3.6 \mathrm{H}), 7.68$ $(\mathrm{d}, J=9.2 \mathrm{~Hz}, 0.8 \mathrm{H}), 7.53(\mathrm{~d}, J=9.2 \mathrm{~Hz}, 1 \mathrm{H}), 7.48(\mathrm{t}, J=7.8 \mathrm{~Hz}, 3.6 \mathrm{H}), 7.36-7.32(\mathrm{~m}, 1.8$ H), 7.04-7.02 (m, $1.8 \mathrm{H}), 6.86(\mathrm{~d}, J=2.0 \mathrm{~Hz}, 0.8 \mathrm{H}), 6.80(\mathrm{dd}, J=8.8,1.6 \mathrm{~Hz}, 1 \mathrm{H}), 3.87(\mathrm{~s}$, $3 \mathrm{H}), 3.82(\mathrm{~s}, 2.4 \mathrm{H}) ;{ }^{13} \mathrm{C} \mathrm{NMR}\left(100 \mathrm{MHz}, \mathrm{CDCl}_{3}\right.$, mixture of isomers) $\delta 159.5,155.6$, 151.0, 146.9, 140.7, 140.6, 129.6, 127.6, 127.5, 122.9, 122.2, 121.4, 120.7, 120.53, 120.50, $119.46,119.41,118.7,118.0,96.4,94.7,55.5,55.4$ (one overlapped signal); LRMS (ESI) $225(\mathrm{M}+\mathrm{H})$; HRMS (ESI) calcd for $\mathrm{C}_{14} \mathrm{H}_{13} \mathrm{~N}_{2} \mathrm{O}(\mathrm{M}+\mathrm{H}) 225.1022$, found 225.1022 .

\section{4-Methyl-2-phenyl-2H-indazole and 7-methyl-2-phenyl-2H-indazole (3fa + 3fa')}

Yellow oil: $R_{f}=0.35\left(5: 1\right.$ hexanes/EtOAc); ${ }^{1} \mathrm{H}$ NMR $\left(400 \mathrm{MHz}, \mathrm{CDCl}_{3}\right.$, mixture of isomers, two sets of signals) $\delta 8.35(\mathrm{~s}, 1 \mathrm{H}), 8.32(\mathrm{~s}, 0.7 \mathrm{H}), 7.88(\mathrm{dd}, J=8.4,2.0 \mathrm{~Hz}, 3.4 \mathrm{H})$, $7.62(\mathrm{~d}, J=8.8 \mathrm{~Hz}, 1 \mathrm{H}), 7.52-7.46(\mathrm{~m}, 4.1 \mathrm{H}), 7.37-7.34(\mathrm{~m}, 1.7 \mathrm{H}), 7.23-7.19(\mathrm{~m}, 1 \mathrm{H})$, 7.07-6.98 (m, 1.4 H), $6.84(\mathrm{~d}, J=6.8 \mathrm{~Hz}, 1 \mathrm{H}), 2.68(\mathrm{~s}, 2.1 \mathrm{H}), 2.54(\mathrm{~s}, 3 \mathrm{H}) ;{ }^{13} \mathrm{C}$ NMR $(100$ $\mathrm{MHz}, \mathrm{CDCl}_{3}$, mixture of isomers) $\delta 150.3,150.0,140.8,140.7,130.7,129.7,128.2,127.93$, 127.89, 127.4, 125.8, 124.3, 122.9, 122.7, 121.7, 121.3, 121.1, 120.9, 119.7, 117.9, 115.4, 19.3, 17.3; LRMS (ESI) $209(\mathrm{M}+\mathrm{H})$; HRMS (ESI) calcd for $\mathrm{C}_{14} \mathrm{H}_{13} \mathrm{~N}_{2}(\mathrm{M}+\mathrm{H})$ 209.1073, found 209.1078 .

\section{2-Phenyl-2 $\mathrm{H}$-benzo[ $\mathrm{g}]$ indazole and 2-phenyl-2H-benzo[e]indazole (3ga $+3 \mathrm{ga}$ ')}

Yellow gel: $R_{f}=0.42\left(5: 1\right.$ hexanes/EtOAc); ${ }^{1} \mathrm{H}$ NMR $\left(400 \mathrm{MHz}, \mathrm{CDCl}_{3}\right.$, mixture of isomers, two sets of signals) $\delta 8.74(\mathrm{~d}, J=8.0 \mathrm{~Hz}, 1 \mathrm{H}), 8.71(\mathrm{~s}, 1 \mathrm{H}), 8.33(\mathrm{~s}, 1 \mathrm{H}), 8.12(\mathrm{~d}$, $J=7.6 \mathrm{~Hz}, 1 \mathrm{H}), 7.93(\mathrm{t}, J=7.2 \mathrm{~Hz}, 4 \mathrm{H}), 7.83(\mathrm{~d}, J=8.0 \mathrm{~Hz}, 2 \mathrm{H}), 7.74(\mathrm{~d}, J=9.2 \mathrm{~Hz}, 1$ $\mathrm{H}), 7.62(\mathrm{~m}, 2 \mathrm{H}), 7.52(\mathrm{~m}, 8 \mathrm{H}), 7.38(\mathrm{~m}, 3 \mathrm{H}) ;{ }^{13} \mathrm{C} \mathrm{NMR}\left(100 \mathrm{MHz}, \mathrm{CDCl}_{3}\right.$, mixture of isomers) $\delta 148.9,147.7,140.7,140.6,132.9,130.6,129.72,129.69,129.3,129.1,128.6$, 127.6, 127.5, 127.4, 127.2, 127.1, 126.9, 125.8, 125.6, 124.7, 123.6, 122.8, 121.2, 120.6, 120.5, 120.2, 120.0, 118.5, 117.9, 117.5; LRMS (ESI) 245 (M+H); HRMS (ESI) calcd for $\mathrm{C}_{17} \mathrm{H}_{13} \mathrm{~N}_{2}(\mathrm{M}+\mathrm{H})$ 245.1073, found 245.1064.

\section{4-Methoxy-2-phenyl-2H-indazole (3ia)}

Following the general procedure, this product was isolated as a white gel by collecting the first spot: $R_{f}=0.24\left(5: 1\right.$ hexanes/EtOAc); ${ }^{1} \mathrm{H} \mathrm{NMR}\left(400 \mathrm{MHz}, \mathrm{CDCl}_{3}\right) \delta 8.48(\mathrm{~s}, 1 \mathrm{H}), 7.89$ $(\mathrm{d}, J=8.1 \mathrm{~Hz}, 2 \mathrm{H}), 7.51(\mathrm{t}, J=7.7 \mathrm{~Hz}, 2 \mathrm{H}), 7.44-7.33(\mathrm{~m}, 2 \mathrm{H}), 7.31-7.18(\mathrm{~m}, 1 \mathrm{H}), 6.35$ $(\mathrm{d}, J=7.3 \mathrm{~Hz}, 1 \mathrm{H}), 3.96(\mathrm{~s}, 3 \mathrm{H}) ;{ }^{13} \mathrm{C}$ NMR $\left(100 \mathrm{MHz}, \mathrm{CDCl}_{3}\right) \delta 153.4,151.2,140.4$, $129.5,127.70,127.65,120.7,119.0,116.8,110.3,98.8,55.2$; LRMS (EI) 224 (M), 209 (M- 
Me); HRMS (EI) calcd for $\mathrm{C}_{14} \mathrm{H}_{12} \mathrm{~N}_{2} \mathrm{O}$ (M) 224.0950, found 224.0950. The 2D NMR spectra and the analysis are included in the SI.

\section{7-Methoxy-2-phenyl-2H-indazole (3ia')}

The second spot of the aforementioned column chromatography afforded a yellow gel: $R_{f}=$ 0.12 (5:1 hexanes/EtOAc). This material was stirred with $1 \mathrm{~mL}$ of $\mathrm{Ac}_{2} \mathrm{O}$ and $1 \mathrm{~mL}$ of pyridine at room temperature for $30 \mathrm{~min}$. Then the volatiles were evaporated under a vacuum, and the product purified by column chromatography: ${ }^{1} \mathrm{H} \mathrm{NMR}\left(400 \mathrm{MHz}, \mathrm{CDCl}_{3}\right)$ $\delta 8.36(\mathrm{~s}, 1 \mathrm{H}), 7.93(\mathrm{~d}, J=8.0 \mathrm{~Hz}, 2 \mathrm{H}), 7.49(\mathrm{t}, J=7.8 \mathrm{~Hz}, 2 \mathrm{H}), 7.37(\mathrm{t}, J=7.4 \mathrm{~Hz}, 1 \mathrm{H})$, $7.26(\mathrm{~d}, J=8.4 \mathrm{~Hz}, 1 \mathrm{H}), 7.02(\mathrm{dd}, J=8.4,0.8 \mathrm{~Hz}, 1 \mathrm{H}), 6.58(\mathrm{~d}, J=7.2 \mathrm{~Hz}, 1 \mathrm{H}), 4.04(\mathrm{~s}, 3$ $\mathrm{H}) ;{ }^{13} \mathrm{C} \mathrm{NMR}\left(100 \mathrm{MHz}, \mathrm{CDCl}_{3}\right) \delta 150.6,143.5,140.5,129.6,128.0,124.5,123.3,121.2$, 120.8, 112.5, 103.3, 55.7; LRMS (ESI) $225(\mathrm{M}+\mathrm{H}), 247(\mathrm{M}+\mathrm{Na}), 471(2 \mathrm{M}+\mathrm{Na})$; HRMS (ESI) calcd for $\mathrm{C}_{14} \mathrm{H}_{13} \mathrm{~N}_{2} \mathrm{O}(\mathrm{M}+\mathrm{H}) 225.1022$, found 225.1024. This regioisomer matches the reported ${ }^{1} \mathrm{H}$ and ${ }^{13} \mathrm{C}$ NMR spectral data. ${ }^{18}$

\section{4-Methoxy-2-(4-methylphenyl)-2H-indazole (3id)}

Following the general procedure, this product was isolated as a white gel by collecting the first spot: $R_{f}=0.30\left(5: 1\right.$ hexanes/EtOAc); ${ }^{1} \mathrm{H}$ NMR $\left(400 \mathrm{MHz}, \mathrm{CDCl}_{3}\right) \delta 8.43(\mathrm{~s}, 1 \mathrm{H}), 7.76$ $(\mathrm{d}, J=7.6 \mathrm{~Hz}, 2 \mathrm{H}), 7.36(\mathrm{~d}, J=8.4 \mathrm{~Hz}, 1 \mathrm{H}), 7.29(\mathrm{~d}, J=7.6 \mathrm{~Hz}, 2 \mathrm{H}), 7.24-7.20(\mathrm{~m}, 1 \mathrm{H})$, 6.34 (d, $J=7.2 \mathrm{~Hz}, 1 \mathrm{H}), 3.94$ (s, $3 \mathrm{H}), 2.40(\mathrm{~s}, 3 \mathrm{H}) ;{ }^{13} \mathrm{C} \mathrm{NMR}\left(100 \mathrm{MHz}, \mathrm{CDCl}_{3}\right) \delta$ 153.6, $151.3,138.3,137.9,130.2,127.7,120.8,119.1,116.9,110.4,98.9,55.4,21.2$; LRMS (ESI) $239(\mathrm{M}+\mathrm{H})$; HRMS (ESI) calcd for $\mathrm{C}_{15} \mathrm{H}_{15} \mathrm{~N}_{2} \mathrm{O}(\mathrm{M}+\mathrm{H}) 239.1179$, found 239.1179.

\section{7-Methoxy-2-(4-methylphenyl)-2H-indazole (3id')}

The second spot of the aforementioned column chromatography afforded a yellow gel: $R_{f}=$ 0.22 (5:1 hexanes/EtOAc). This material was stirred with $1 \mathrm{~mL}$ of $\mathrm{Ac}_{2} \mathrm{O}$ and $1 \mathrm{~mL}$ of pyridine at room temperature for $30 \mathrm{~min}$. Then the volatiles were evaporated under vacuum, and the product purified by column chromatography: ${ }^{1} \mathrm{H}$ NMR $\left(400 \mathrm{MHz}, \mathrm{CDCl}_{3}\right) \delta 8.31$ (s, $1 \mathrm{H}), 7.80(\mathrm{~d}, J=8.4 \mathrm{~Hz}, 2 \mathrm{H}), 7.26(\mathrm{t}, J=9.2 \mathrm{~Hz}, 3 \mathrm{H}), 7.01(\mathrm{t}, J=7.8 \mathrm{~Hz}, 1 \mathrm{H}), 6.57(\mathrm{~d}, J$ $=7.6 \mathrm{~Hz}, 1 \mathrm{H}), 4.03(\mathrm{~s}, 3 \mathrm{H}), 2.39(\mathrm{~s}, 3 \mathrm{H}) ;{ }^{13} \mathrm{C} \mathrm{NMR}\left(100 \mathrm{MHz}, \mathrm{CDCl}_{3}\right) \delta 150.5,143.3$, 138.3, 137.9, 130.0, 124.4, 123.1, 121.0, 120.6, 112.4, 103.1, 55.6, 21.2; LRMS (ESI) 239 $(\mathrm{M}+\mathrm{H}), 261(\mathrm{M}+\mathrm{Na})$; HRMS (ESI) calcd for $\mathrm{C}_{15} \mathrm{H}_{14} \mathrm{~N}_{2} \mathrm{ONa}(\mathrm{M}+\mathrm{Na}) 261.0998$, found 261.0999 .

\section{Procedure for the Suzuki-Miyaura Coupling with Boronic Acids}

To a 4 dram vial were added the starting material 3at $(\sim 0.4 \mathrm{mmol})$, the boronic acid (1.5 equiv.), $\mathrm{KOH}$ (3.0 equiv.) and $\mathrm{Pd}\left(\mathrm{PPh}_{3}\right)_{4}(5 \mathrm{~mol} \%)$ in $20: 5: 1$ toluene/ethanol/ $\mathrm{H}_{2} \mathrm{O}(4 \mathrm{~mL}$ in total). The solution was vigorously stirred for $5 \mathrm{~min}$ at room temperature, flushed with argon and sealed, and then heated to $80^{\circ} \mathrm{C}$ until TLC revealed complete conversion of the starting material. Upon cooling to room temperature, the resulting reaction mixture was diluted with water and extracted with EtOAc. The combined organic layers were dried over $\mathrm{MgSO}_{4}$, concentrated, and purified by column chromatography to afford the following product.

\section{3-(3,4-Methylenedioxyphenyl)-2-phenyl-2H-indazole (4at)}

Following the general procedure, this product was isolated as a brown solid: $\mathrm{mp} 154-156^{\circ} \mathrm{C}$; $R_{f}=0.31\left(5: 1\right.$ hexanes/EtOAc); ${ }^{1} \mathrm{H}$ NMR $\left(400 \mathrm{MHz}, \mathrm{CDCl}_{3}\right) \delta 7.78(\mathrm{~d}, J=8.8 \mathrm{~Hz}, 1 \mathrm{H})$, $7.68(\mathrm{~d}, J=8.8 \mathrm{~Hz}, 1 \mathrm{H}), 7.45(\mathrm{~d}, J=6.8 \mathrm{~Hz}, 2 \mathrm{H}), 7.42-7.33(\mathrm{~m}, 4 \mathrm{H}), 7.12(\mathrm{dd}, J=8.0,7.2$ $\mathrm{Hz}, 1 \mathrm{H}), 6.87-6.81(\mathrm{~m}, 2 \mathrm{H}), 6.78(\mathrm{~s}, 1 \mathrm{H}), 5.98(\mathrm{~s}, 2 \mathrm{H}) ;{ }^{13} \mathrm{C} \mathrm{NMR}\left(100 \mathrm{MHz}, \mathrm{CDCl}_{3}\right) \delta$ $149.0,148.1,147.9,140.2,135.3,129.2,128.4,127.2,126.1,124.0,123.5,122.5,121.8$, 
120.6, 117.8, 110.0, 108.9, 101.5; LRMS (ESI) 315 (M+H); HRMS (ESI) calcd for

$\mathrm{C}_{20} \mathrm{H}_{15} \mathrm{~N}_{2} \mathrm{O}_{2}(\mathrm{M}+\mathrm{H}) 315.1128$, found 315.1125 .

\section{Procedure for the Sonogashira Coupling with a Terminal Alkyne}

To a 4 dram vial was added the starting material 3at $(\sim 0.4 \mathrm{mmol})$, the alkyne (1.2 equiv.), $\mathrm{PdCl}_{2}\left(\mathrm{PPh}_{3}\right)_{2}$ (3 mol \%), CuI (3 mol \%), DMF (1.5 mL) and $\mathrm{Et}_{2} \mathrm{NH}(1.5 \mathrm{~mL})$. The solution was stirred at room temperature, flushed with argon and sealed, and then heated to $60{ }^{\circ} \mathrm{C}$ until TLC analysis revealed complete conversion of the starting material. The solution was allowed to cool and diluted with EtOAc. The combined organic layers were dried over $\mathrm{MgSO}_{4}$, concentrated, and purified by column chromatography to afford the following product.

\section{3-(3-Methoxyprop-1-ynyl)-2-phenyl-2H-indazole (5at)}

Yellow oil: $R_{f}=0.25\left(5: 1\right.$ hexanes/EtOAc); ${ }^{1} \mathrm{H}$ NMR $\left(400 \mathrm{MHz}, \mathrm{CDCl}_{3}\right) \delta 7.91(\mathrm{~d}, J=7.6$ $\mathrm{Hz}, 2 \mathrm{H}), 7.78$ (dd, $J=15.6,8.8 \mathrm{~Hz}, 2 \mathrm{H}), 7.53$ (t, $J=7.8 \mathrm{~Hz}, 2 \mathrm{H}), 7.46$ (t, $J=7.2 \mathrm{~Hz}, 1 \mathrm{H}$ ), $7.36(\mathrm{t}, J=7.6 \mathrm{~Hz}, 1 \mathrm{H}), 7.20(\mathrm{t}, J=7.4 \mathrm{~Hz}, 1 \mathrm{H}), 4.41(\mathrm{~s}, 2 \mathrm{H}), 3.43(\mathrm{~s}, 3 \mathrm{H}) ;{ }^{13} \mathrm{C} \mathrm{NMR}$ $\left(100 \mathrm{MHz}, \mathrm{CDCl}_{3}\right) \delta 148.7,140.2,129.2,128.9,127.5,126.1,124.7,123.6,120.2,118.5$, 117.7, 96.7, 75.4, 60.7, 58.0; LRMS (ESI) $263(\mathrm{M}+\mathrm{H})$; HRMS (ESI) calcd for $\mathrm{C}_{17} \mathrm{H}_{15} \mathrm{~N}_{2} \mathrm{O}$ $(\mathrm{M}+\mathrm{H})$ 263.1179, found 263.1180.

\section{Supplementary Material}

Refer to Web version on PubMed Central for supplementary material.

\section{Acknowledgments}

We thank the National Institutes of Health (GM070620 and GM079593 to R.C.L.), the National Institutes of Health Center for Chemical Methodology and Library Development at University of Kansas (P50 GM069663 to R.C.L.), the National Natural Science Foundation of China (No. 21002021 to F.S.), and the Key Project of the Chinese Ministry of Education (No. 210127 to F.S.) for their generous financial support, and the State Key Laboratory of Physical Chemistry of Solid Surfaces (Xiamen University) for providing computational resources. We also thank Mr. Donald C. Rogness (Iowa State University) for his help in preparation of the benzyne precursors, and Mr. Yong Wang (Henan University), Dr. Jiang Zhou (Peking University), Mr. Shu-Lun Tang and Dr. Kermal Harrata (both Iowa State University) for their help in the spectroscopic analysis.

\section{References}

1. (a) Schmidt A, Beutler A, Snovydovych B. Eur J Org Chem. 2008:4073.(b) Clutterbuck LA, Posada CG, Visintin C, Riddal DR, Lancaster B, Gane PJ, Garthwaite J, Selwood DL. J Med Chem. 2009; 52:2694. [PubMed: 19341281]

2. (a) Andreonati S, Sava V, Makan S, Kolodeev G. Pharmazie. 1999; 54:99. [PubMed: 10084155] (b) Paluchowska MH, Duszynska B, Klodzinska A, Tatarzynska E. Pol J Pharmacol. 2000; 52:209. [PubMed: 11055578] (c) Saczewski F, Saczewski J, Hudson AL, Tyacke RJ, Nutt DJ, Man J, Tabin P. Eur J Pharm Sci. 2003; 20:201. [PubMed: 14550886] (d) Angelis MD, Stossi F, Carlson KA, Katzenellenbogen BS, Katzenellenbogen JA. J Med Chem. 2005; 48:1132. [PubMed: 15715479]

3. (a) Halland N, Nazaré M, R'kyek O, Alonso J, Urmann M, Lindenschmidt A. Angew Chem Int Ed. 2009; 48:6879.(b) Song JJ, Yee NK. Org Lett. 2000; 2:519. [PubMed: 10814366] (c) Haag B, Peng Z, Knochel P. Org Lett. 2009; 11:4270. [PubMed: 19775181] (d) Taher A, Ladwa S, Rajan ST, Weaver GW. Tetrahedron Lett. 2000; 41:9893.(e) Varughese DJ, Manhas MS, Bose AK. Tetrahedron Lett. 2006; 47:6795.(f) Lee KY, Gowrisankar S, Kim JN. Tetrahedron Lett. 2005; 46:5387.(g) Kumar MR, Park A, Park N, Lee S. Org Lett. 2011; 13:3542. [PubMed: 21644532]

4. (a) Liu Z, Zhang X, Larock RC. J Am Chem Soc. 2005; 127:15716. [PubMed: 16277509] (b) Zhang X, Larock RC. Org Lett. 2005; 7:3973. [PubMed: 16119945] (c) Liu Z, Larock RC. Org Lett. 2004; 6:3739. [PubMed: 15469337] (d) Liu Z, Larock RC. Tetrahedron. 2007; 63:347. [PubMed: 18180808] (e) Henderson JL, Edwards AS, Greaney MF. J Am Chem Soc. 2006; 128:7426. 
[PubMed: 16756281] (f) Jayanth TT, Cheng CH. Chem Commun. 2006; 894(g) Peña D, Pérez D, Guitián E, Castedo L. Org Lett. 1999; 1:1555.(h) Radhakrishnan KV, Yoshikawa E, Yamamoto Y. Tetrahedron Lett. 1999; 40:7533.(i) Peña D, Pérez D, Guitián E, Castedo L. J Am Chem Soc. 1999; 121:5827.

5. (a) Yoshida H, Honda Y, Shirakawa E, Hiyama T. Chem Commun. 2001; 1880(b) Yoshida H, Shirakawa E, Honda Y, Hiyama T. Angew Chem Int Ed Engl. 2002; 41:3247. [PubMed: 12207403] (c) Liu Z, Larock RC. Org Lett. 2003; 5:4673. [PubMed: 14627412] (d) Liu Z, Larock RC. Org Lett. 2004; 6:99. [PubMed: 14703360] (e) Jeganmohan M, Cheng CH. Synthesis. 2005:1693.(f) Bhuvaneswari S, Jeganmohan M, Yang MC, Cheng CH. Chem Commun. 2008:2158.

6. (a) Raminelli C, Liu Z, Larock RC. J Org Chem. 2006; 71:4689. [PubMed: 16749809] (b) Feltenberger JB, Hayashi R, Tang Y, Babiash ESC, Hsung RP. Org Lett. 2009; 11:3430. [PubMed: 19591454] (c) Allan KM, Stoltz BM. J Am Chem Soc. 2008; 130:17270. [PubMed: 19035638] (d) Gilmore CD, Allan KM, Stoltz BM. J Am Chem Soc. 2008; 130:1558. [PubMed: 18193875] (e) Pérez D, Guitián E, Castedo L. J Org Chem. 1992; 57:5911.(f) Matsumoto T, Hosoya T, Suzuki K. J Am Chem Soc. 1992; 114:3568.(g) Hosoya T, Takashiro E, Matsumoto T, Suzuki K. J Am Chem Soc. 1994; 116:1004.(h) Hussain H, Kianmehr E, Durst T. Tetrahedron Lett. 2001; 42:2245.(I) Soorukram D, Qu T, Barrett AGM. Org Lett. 2008; 10:3833. [PubMed: 18672878]

7. (a) Liu Z, Larock RC. J Am Chem Soc. 2005; 127:13112. [PubMed: 16173716] (b) Tambar UK, Stoltz BM. J Am Chem Soc. 2005; 127:5340. [PubMed: 15826170]

8. Shi F, Waldo JP, Chen Y, Larock RC. Org Lett. 2008; 10:2409. [PubMed: 18476707]

9. Liu Z, Shi F, Martinez PDG, Raminelli C, Larock RC. J Org Chem. 2008; 73:219. [PubMed: 18067316]

10. Dubrovskiy AV, Larock RC. Org Lett. 2010; 12:1180. [PubMed: 20184347]

11. Wu C, Fang Y, Larock RC, Shi F. Org Lett. 2010; 12:2234. [PubMed: 20394430]

12. (a) Thoman CJ, Voaden DJ. Org Synth. 1965; 45:96.(b) Baker W, Ollis WD, Poole VD. J Chem Soc. 1950:1542.(c) Applegate J, Turnbull K. Synthesis. 1988:1011.(d) Azarifar D, GhasemnejadBorsa H. Synthesis. 2006:1123.(e) Azarifar D, Ghasemnejad-Borsa H, Tajbaksh M, Habibzadeh S. Heterocycles. 2007; 71:1815.(f) Ma D, Cai Q, Zhang H. Org Lett. 2003; 5:2453. [PubMed: 12841753] (g) Browne DL, Vivat JF, Plant A, Gomez-Bengoa E, Harrity JPA. J Am Chem Soc. 2009; 131:7762. [PubMed: 19449876]

13. Rodriguez A, Fennessy RV, Moran WJ. Tetrahedron Lett. 2009; 50:3942.

14. Wu C, Li P, Fang Y, Zhao J, Xue W, Li Y, Larock RC, Shi F. Tetrahedron Lett. 2011; 52:3797. 15. Browne DL, Taylor AP, Harrity JP. J Org Chem. 2010; 75:984. [PubMed: 20030356]

16. Ghasemnejad-Bosra H, Haghdadi M, Gholampour-Azizi I. Heterocycles. 2008; 75:391.

17. (a) Effenberger F, Daub W. Chem Ber. 1991; 124:2119.(b) Walters M, Shay J. Synth Commun. 1997; 27:3573.

18. Ohnmacht SA, Culshaw AJ, Greaney MF. Org Lett. 2010; 12:224. [PubMed: 20014781]

19. Kessar, SV. Comprehensive Organic Synthesis. Trost, BM.; Fleming, I., editors. Vol. 4. Pergamon Press; Oxford, England: 1991. p. 483-515.

20. (a) Hill R, Sutton LE, Longuet-Higgins C. J Chem Phys. 1949; 46:244.(b) Orgel LE, Cotterell TL, Dick W, Sutton LE. Trans Faraday Soc. 1951; 47:113.

21. Fan J, Wang Y, Ueng C. J Phys Chem. 1993; $97: 8193$.

22. For regioselectivities in favor of $C-4$ reacting as the nucleophilic site, see:(a) Padwa A, Burgess EM, Gingrich HL, Roush DM. J Org Chem. 1982; 47:786.(b) Chang E, Wong FF, Chen T, Chiang K, Yeh M. Heterocycles. 2006; 68:1007.(c) Fariña F, Fernández P, Fraile MT, Martín MV, Martín MR. Heterocycles. 1989; 29:967.(d) Harju K, Vesterinen J, Yli-Kauhaluoma J. Org Lett. 2009; 11:2219. [PubMed: 19419217] For regioselectivities in favor of $N$-2 reacting as the nucleophilic site, see(e) Hegde JC, Rai G, Puranik VG, Kalluraya B. Synth Commun. 2006; 36:1285.(f) Croce PD, Rosa CL, Zecchi G. J Chem Soc, Perkin Trans 1. 1985:2621.

23. (a) Padwa A, Burgess EM, Gingrich HL, Roush DM. J Org Chem. 1982; 47:786.(b) Houk KN, Sims J, Duke RE, Strozier RW, George JK. J Am Chem Soc. 1973; 95:7287.

24. The reaction between resonance structure $\mathbf{C}$ and aryne leads to a closer approximity between the carbonyl group of the sydnone and the OMe group of the aryne. Such steric repulsion does not exist if resonance structure $\mathbf{B}$ is reacting. 
25. Miyaura N, Suzuki A. Chem Rev. 1995; 95:2457.

26. (a) Negishi E, Anastasia L. Chem Rev. 2003; 103:1979. [PubMed: 12744698] (b) Miura M, Nomura M. Top Curr Chem. 2002; 219:211.

27. Cho C, Neuenswander B, Lushington GH, Larock RC. J Comb Chem. 2008; 10:941. [PubMed: 18937516]

28. For an improved synthesis of aryne precursors bearing diverse functional groups, see:(a) Kirkham JD, Delaney PM, Ellames GJ, Rowb EC, Harrity JPA. Chem Commun. 2010; 46:5154.(b) Crossley JA, Kirkham JD, Browne DL, Harrity JPA. Tetrahedron Lett. 2010; 51:6608.

29. (a) Peña D, Pérez D, Guitián E, Castedo L. J Am Chem Soc. 1999; 121:5827.(b) Peña D, Pérez D, Guitián E, Castedo L. J Org Chem. 2000; 65:6944. [PubMed: 11031014] (c) Yoshida H, Sugiura S, Kunai A. Org Lett. 2002; 4:2767. [PubMed: 12153230] (d) Liu Z, Zhang X, Larock RC. J Am Chem Soc. 2005; 127:15716. [PubMed: 16277509] (e) Peña D, Escudero S, Pérez D, Guitián E, Castedo L. Angew Chem, Int Ed Engl. 1998; 37:2659.(f) Yoshida H, Ikadai J, Shudo M, Ohshita J, Kunai A. J Am Chem Soc. 2003; 125:6638. [PubMed: 12769566] (g) Himeshima Y, Sonoda T, Kobayashi H. Chem Lett. 1983:1211.(h) Peña D, Cobas A, Pérez D, Guitian E. Synthesis. 2002:1454.

30. These two types of silica gel are noticeably different. We have observed that much higher $R_{f}$ values are obtained using the 300-400 mesh silica gel.

31. Frisch, MJ.; Trucks, GW.; Schlegel, HB.; Scuseria, GE.; Robb, MA.; Cheeseman, JR.; Scalmani, G.; Barone, V.; Mennucci, B.; Petersson, GA.; Nakatsuji, H.; Caricato, M.; Li, X.; Hratchian, HP.; Izmaylov, AF.; Bloino, J.; Zheng, G.; Sonnenberg, JL.; Hada, M.; Ehara, M.; Toyota, K.; Fukuda, R.; Hasegawa, J.; Ishida, M.; Nakajima, T.; Honda, Y.; Kitao, O.; Nakai, H.; Vreven, T.; Montgomery, JA., Jr; Peralta, JE.; Ogliaro, F.; Bearpark, M.; Heyd, JJ.; Brothers, E.; Kudin, KN.; Staroverov, VN.; Kobayashi, R.; Normand, J.; Raghavachari, K.; Rendell, A.; Burant, JC.; Iyengar, SS.; Tomasi, J.; Cossi, M.; Rega, N.; Millam, NJ.; Klene, M.; Knox, JE.; Cross, JB.; Bakken, V.; Adamo, C.; Jaramillo, J.; Gomperts, R.; Stratmann, RE.; Yazyev, O.; Austin, AJ.; Cammi, R.; Pomelli, C.; Ochterski, JW.; Martin, RL.; Morokuma, K.; Zakrzewski, VG.; Voth, GA.; Salvador, P.; Dannenberg, JJ.; Dapprich, S.; Daniels, AD.; Farkas, Ö.; Foresman, JB.; Ortiz, JV.; Cioslowski, J.; Fox, DJ. Gaussian 09, Revision A.1. Gaussian, Inc.; Wallingford CT: 2009.

32. Rai NS, Kalluraya B, Lingappa B, Shenoy S, Puranic VG. Eur J Med Chem. 2008; 43:1715. [PubMed: 17923171]

33. Meo PL, D'Anna F, Riela S, Gruttadauria M, Noto R. Org Biomol Chem. 2003; 1:1584. [PubMed: 12926291]

34. (a) Ranganathan D, Bamezai S. Tetrahedron Lett. 1983; 24:1067.(b) Nikitenko AA, Winkley MW, Zeldis J, Kremer K, Chan AWY, Strong H, Jennings M, Jirkovsky I, Blum D, Khafizova G, Grosu GT, Venkatesan AM. Org Proc Res Dev. 2006; 10:712.

35. Cadogan JIG, Mackie RK. Org Synth. 1968; 48:113.

36. The underlined $R_{f}$ values were obtained using the $300-400$ mesh silica gel. The rest of the $R_{f}$ values were obtained using the 230-400 mesh silica gel. These two types of silica gels behave quite differently.

37. Ina S, Inoue S, Noguchi I. Yakugaku Zasshi: J Pharm Soc Jpn. 1975; 95:1245. 

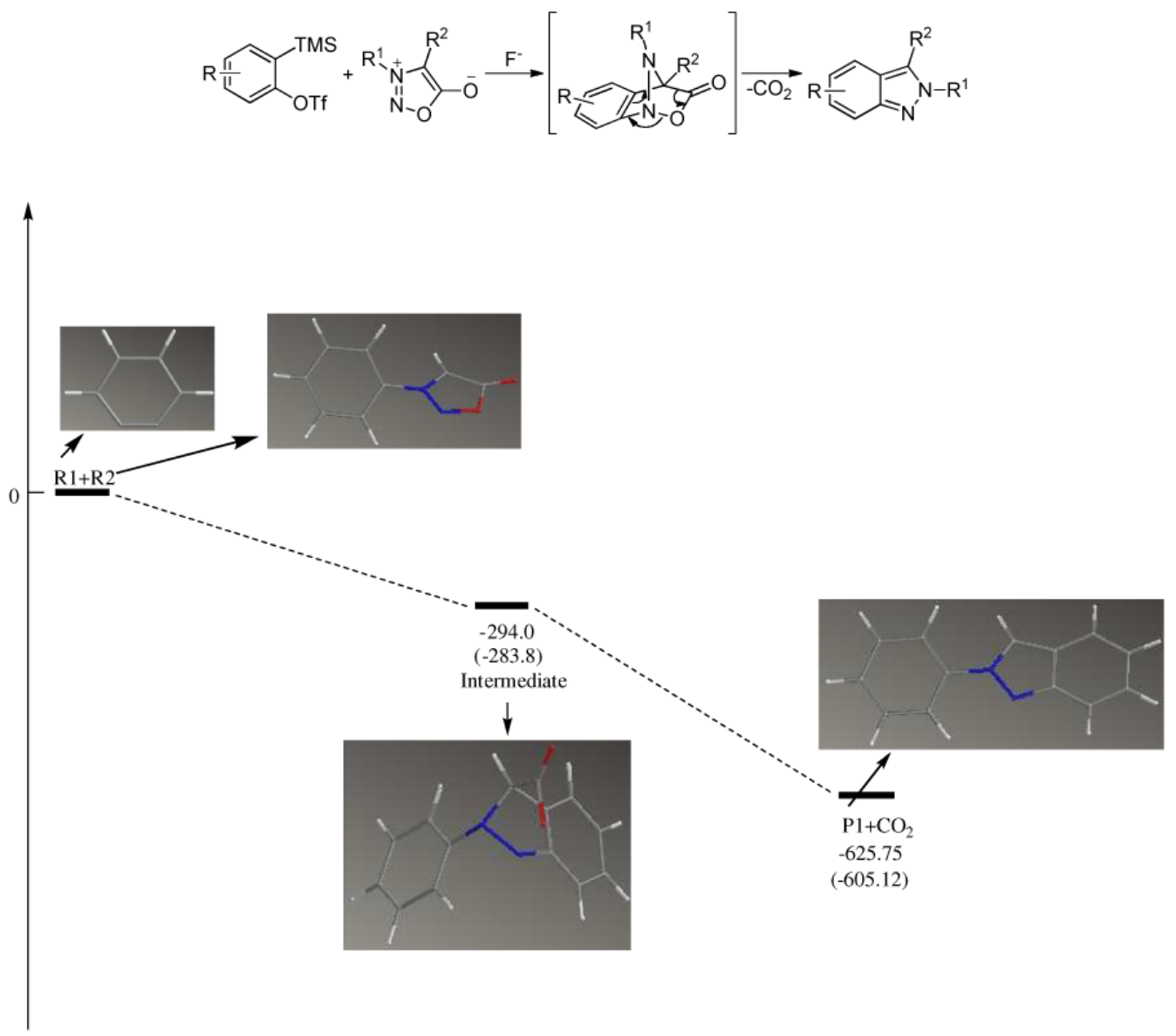

Figure 1.

Schematic potential energy surface with zero-point energy (ZPE) corrections at the $\mathrm{MP} 2 / 6-311+\mathrm{G}(\mathrm{d}, \mathrm{p})$ level (units in $\mathrm{kJ} \mathrm{mol}^{-1}$ ). The values in parentheses are those obtained at the B3LYP/6-31G(d) level. The energy of the reactants is set to zero as a reference. 


$$
\text { Protocol 1A, 1B or 1C }
$$

Scheme 1.

Synthesis of Sydnones. 


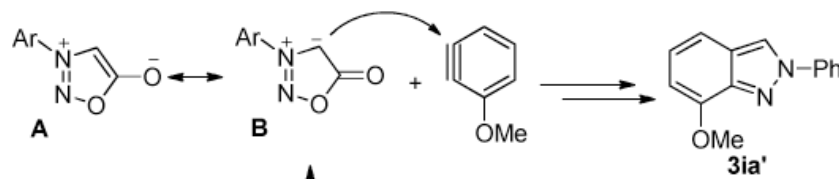

$\uparrow$
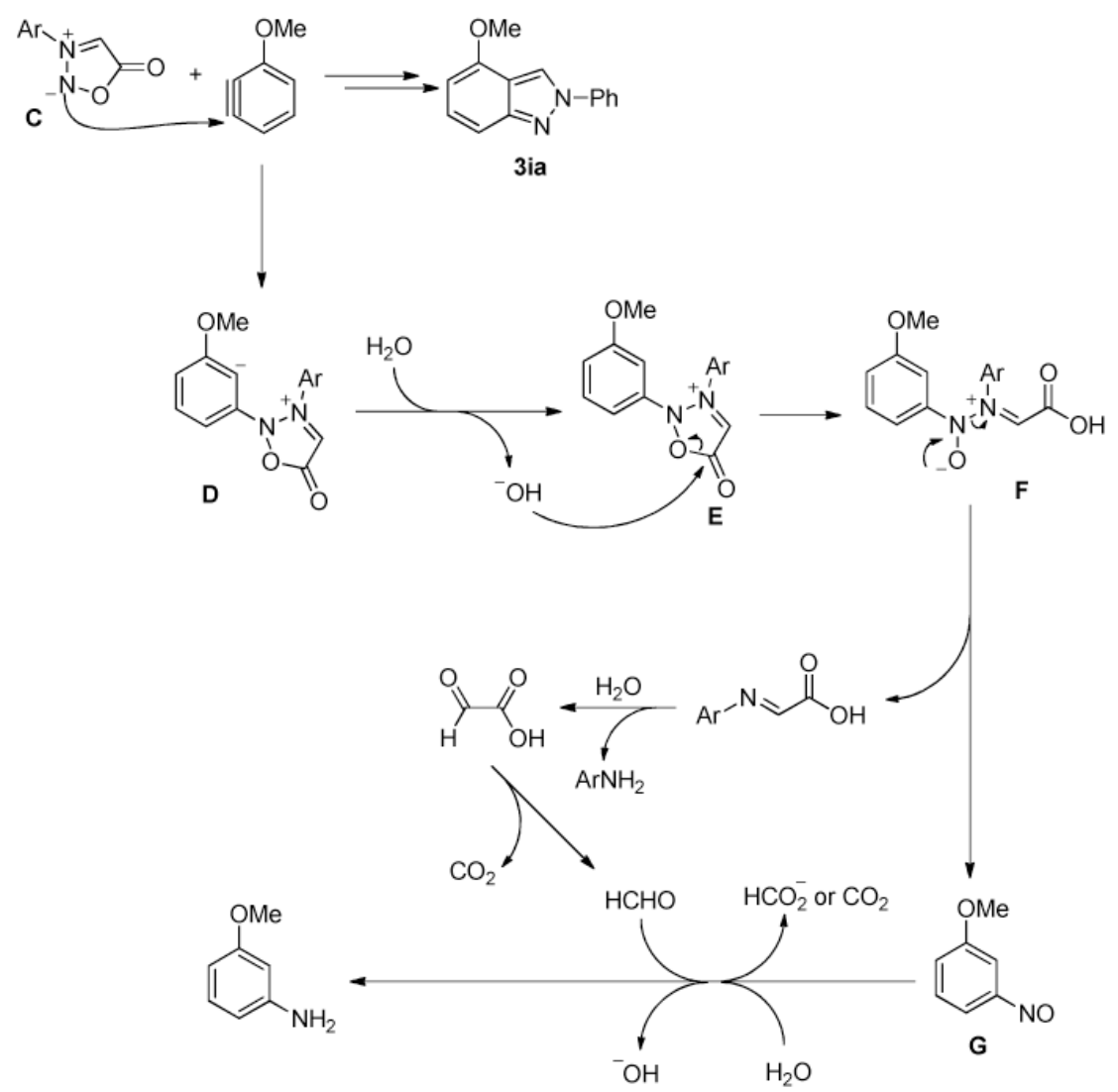

Scheme 2.

Regioselectivity in the Cycloaddition Reaction and Proposed Mechanism for the Formation of $m$-Anisidine. 


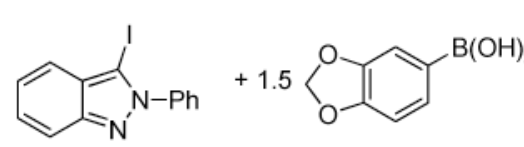

3at

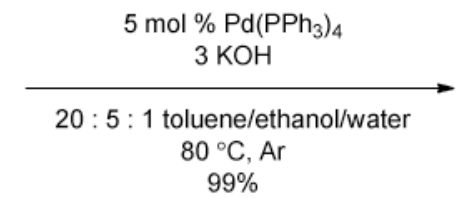
$99 \%$

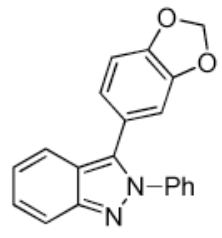

4at

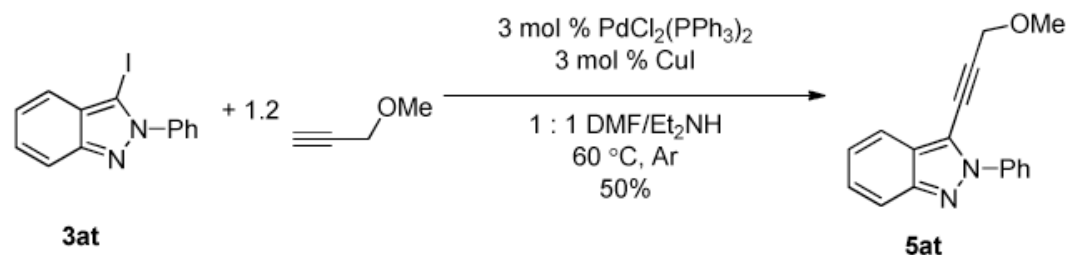

Scheme 3.

Suzuki-Miyaura and Sonogashira Coupling of $2 \mathrm{H}$-Indazoles 


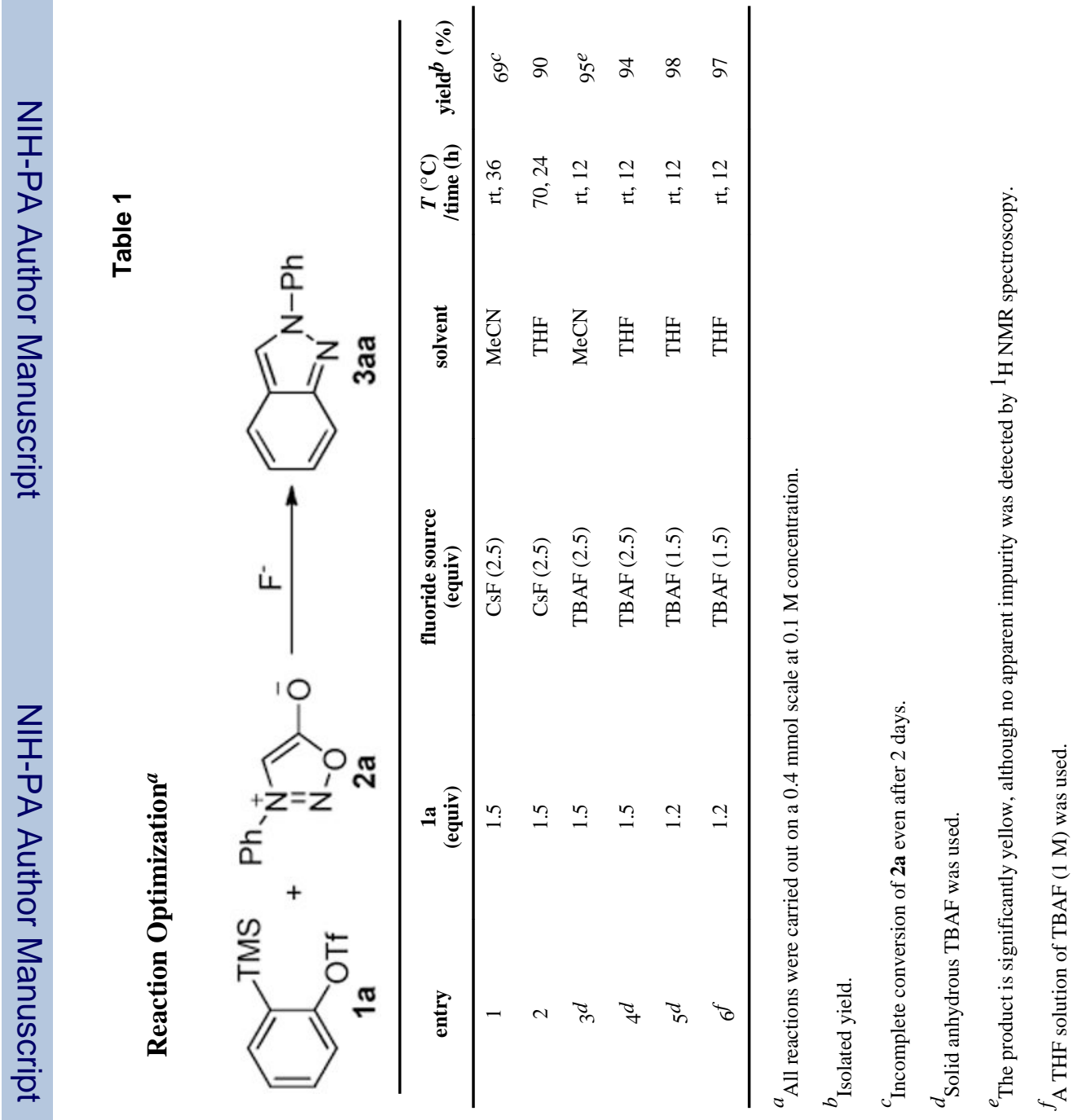

J Org Chem. Author manuscript; available in PMC 2012 November 4. 


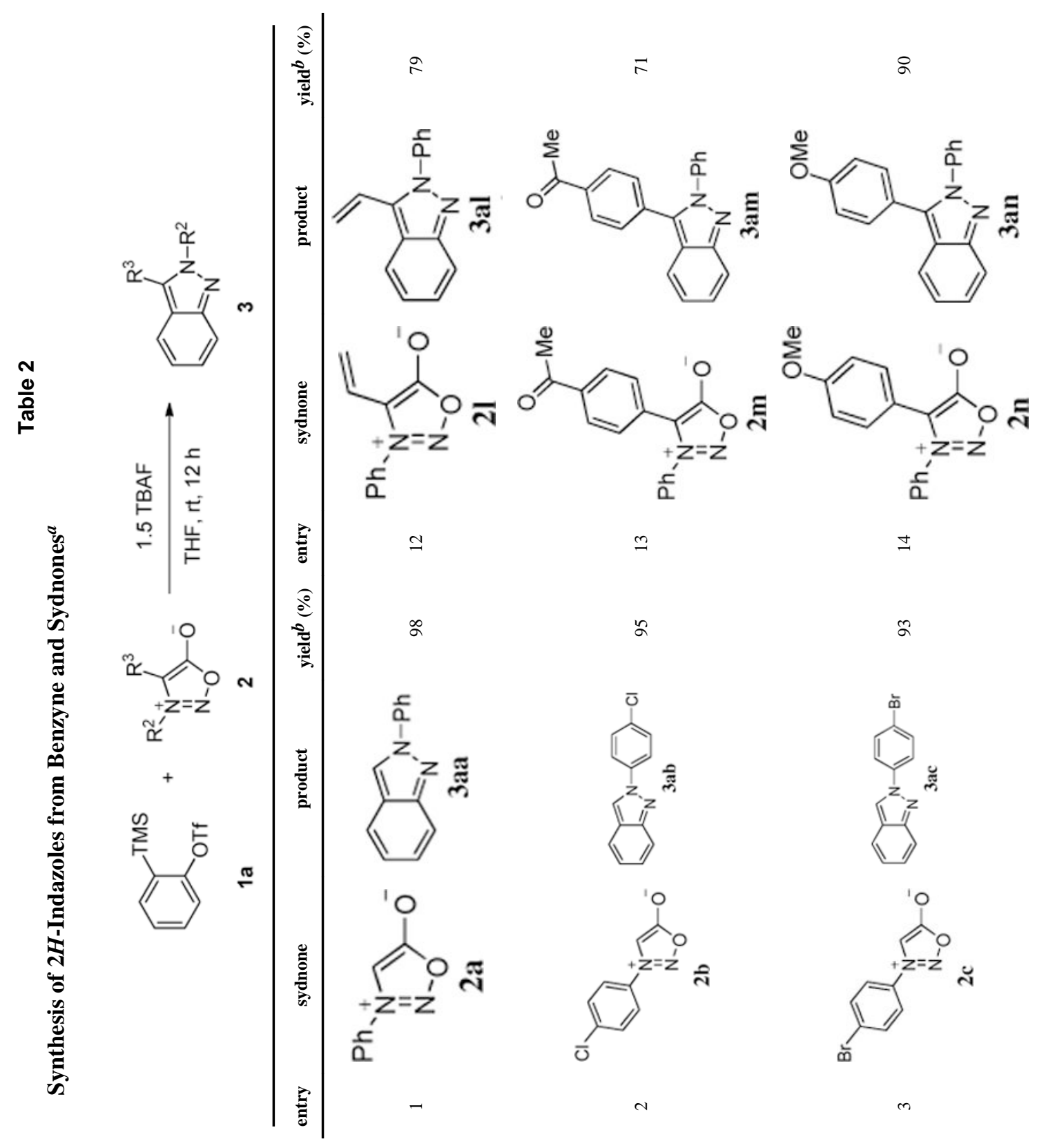




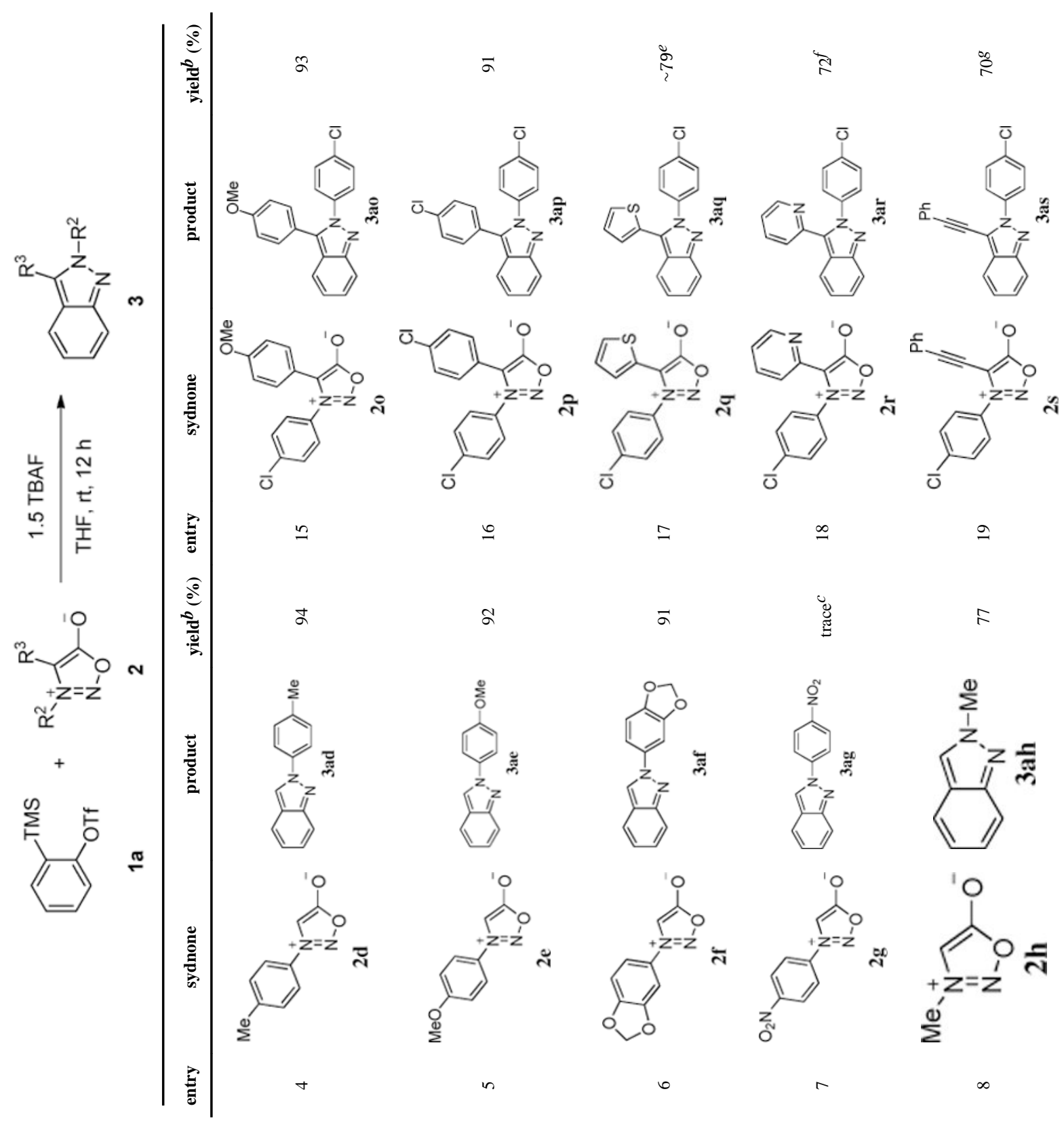



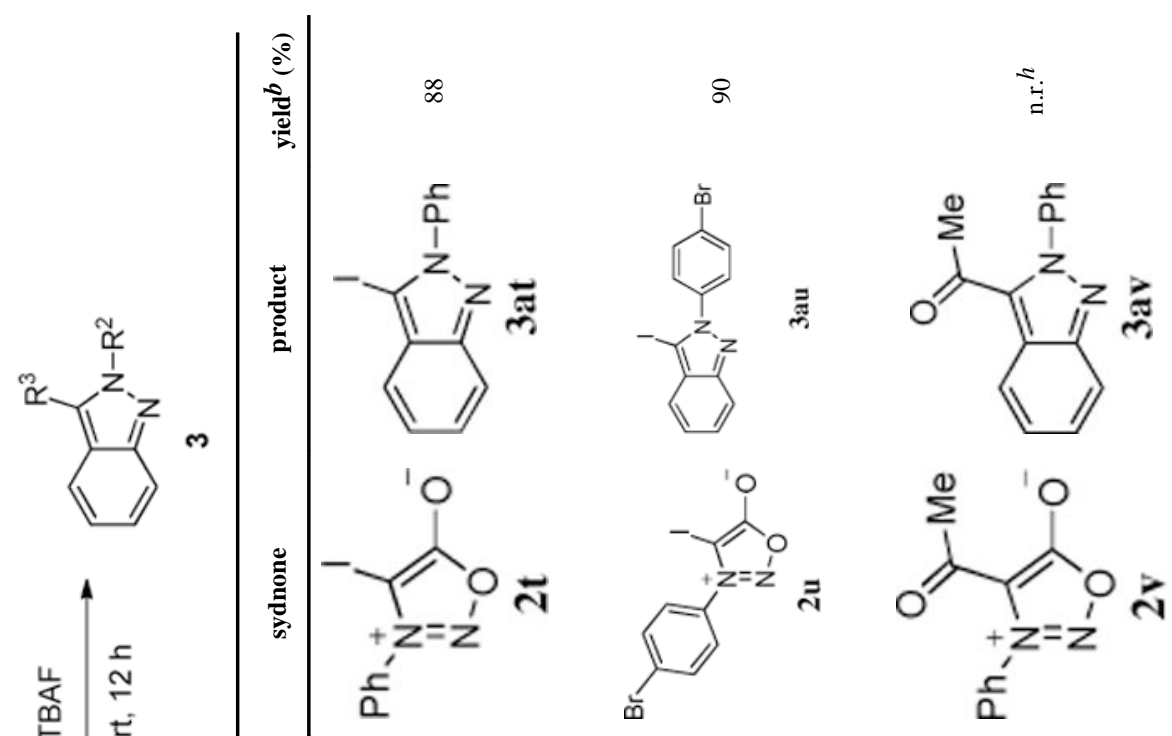

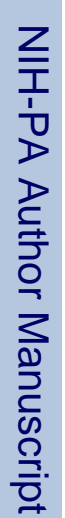
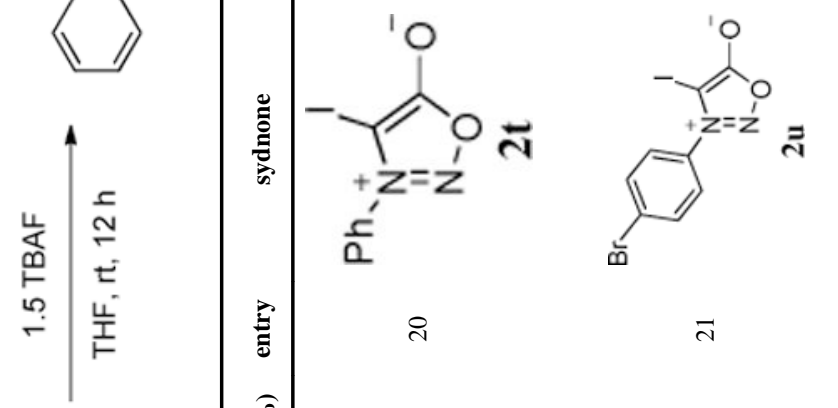<smiles>[13CH3][14c]1[14c](O)[14cH]o[14c]1[14CH3]</smiles>

$$
\stackrel{2}{\frac{2}{2}}
$$

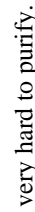

$$
\text { i }
$$

$\bar{\sim}$<smiles>[Y4][Z4]1coc(O)c1[Z10]</smiles><smiles>C1CC2CCC12</smiles>

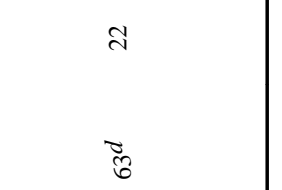

$\dot{\Sigma}$
$\vdots 0$
0
0
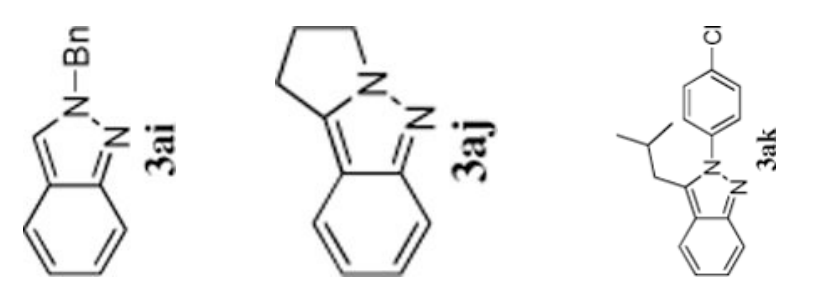<smiles></smiles><smiles>CC(C)Cc1c(O)oc(-c2ccc(O)cc2)c1C(C)C</smiles>

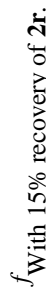




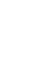


Table 3

\section{Reaction with Other Aryne Precursors ${ }^{a}$}

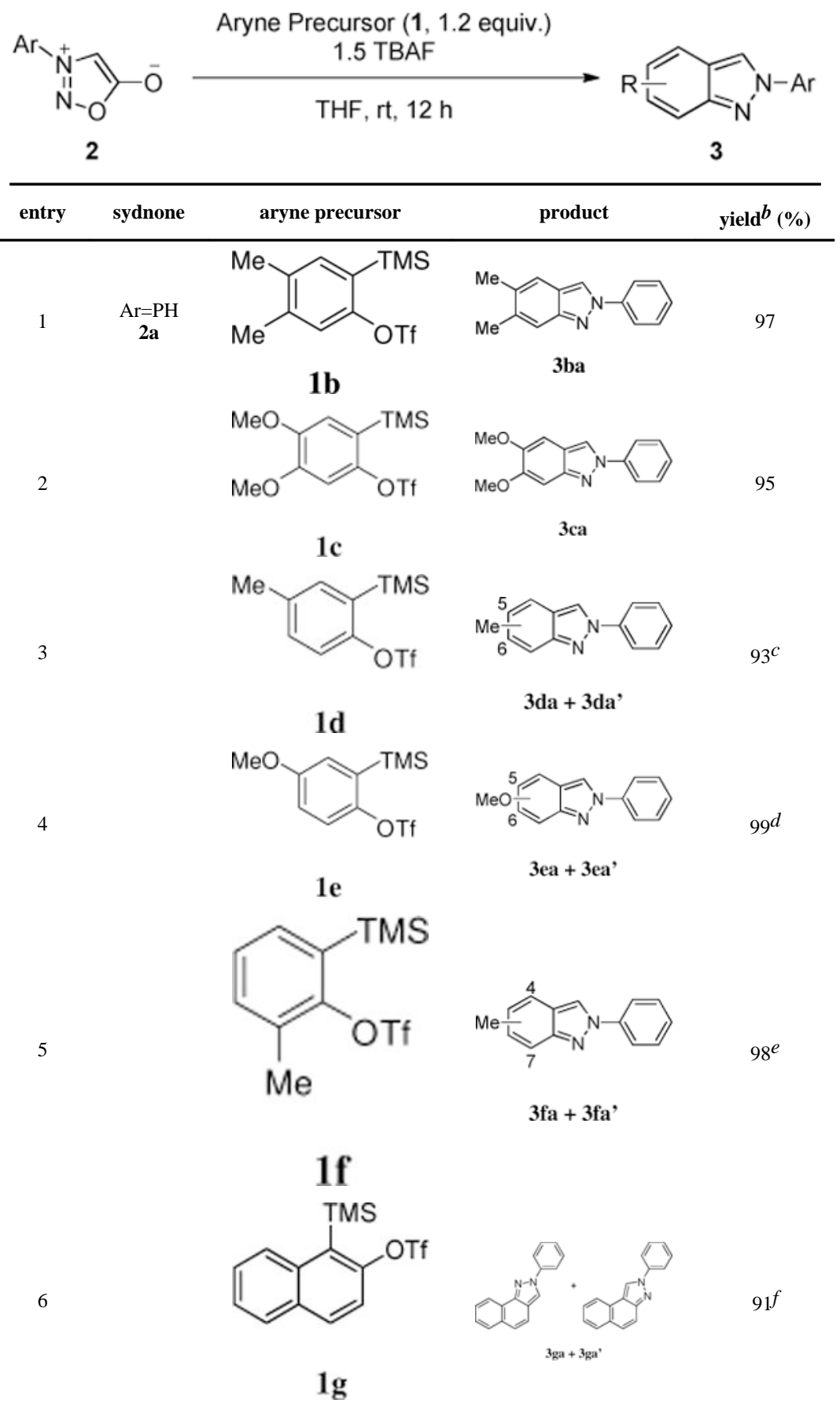

J Org Chem. Author manuscript; available in PMC 2012 November 4. 


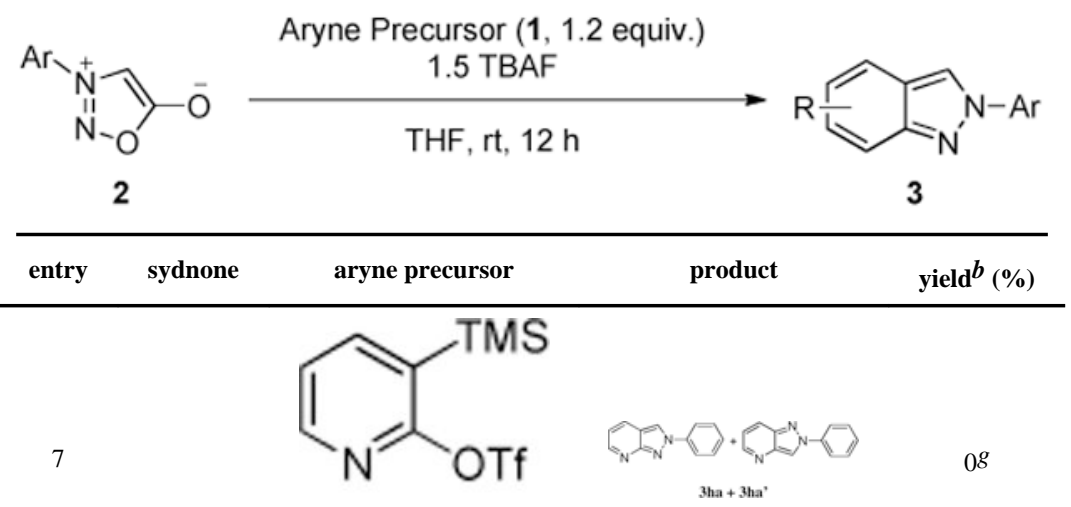

8<smiles>CCOc1cccc(OC)c1S(C)(=O)=O</smiles>

1i

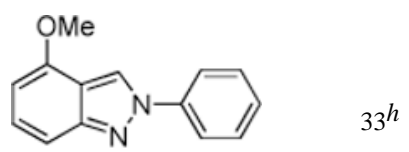

3 ia

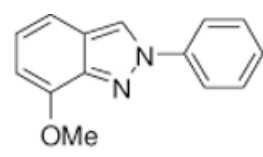

3ia'
40 $44^{i}$

\section{1i}

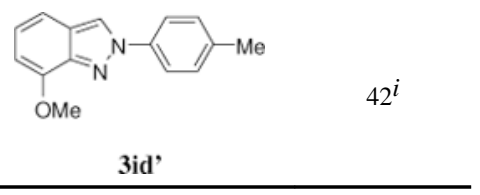

\footnotetext{
${ }^{a}$ All reactions were carried out on $0.4 \mathrm{mmol}$ of sydnone at a concentration of $0.1 \mathrm{M}$.

$b_{\text {Isolated yield. }}$

${ }^{c}$ A 1:1 mixture of the 5-Me isomer and the 6-Me isomer was obtained.

${ }^{d}$ An inseparable 0.8:1 mixture of two isomers (5-MeO and 6-MeO) was obtained. The major isomer was not identified.

${ }^{e}$ A 0.7:1 mixture of two inseparable isomers (4-Me and 7-Me) was obtained. The major isomer was not identified.
} 
$f_{\text {A 1:1 mixture of 3ga and 3ga' was obtained. }}$

${ }^{g}$ All sydnone starting material was recovered when precursor $\mathbf{1 h}$ was consumed.

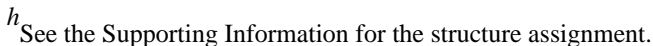

${ }^{i}$ The structures were assigned based on the polarity and ${ }^{1} \mathrm{H}$ NMR coupling pattern of the two isomers obtained from entry 6 . 